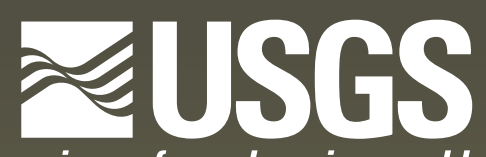

science for a changing world

Prepared in cooperation with the U.S. Navy

\title{
Groundwater Levels and Generalized Potentiometric Surfaces, Former Naval Air Warfare Center, West Trenton, New Jersey, 2018
}

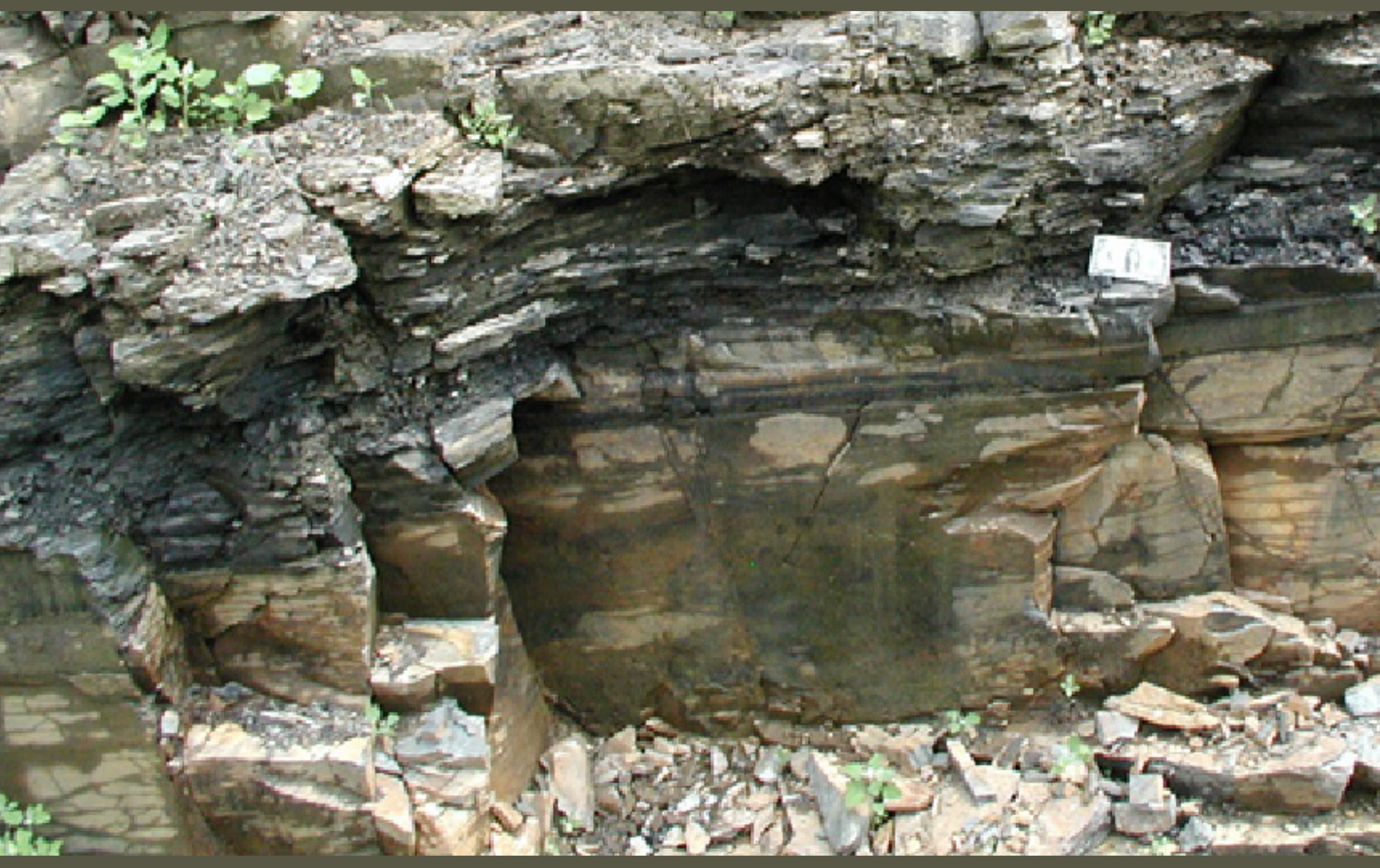

Open-File Report 2020-1016 
Cover: Roadcut exposure of a black fissile mudstone bed of the Lockatong

Formation, Ewing Township, New Jersey. U.S. dollar bill for scale. Credit: Pierre Lacombe, USGS. 


\section{Groundwater Levels and Generalized Potentiometric Surfaces, Former Naval Air Warfare Center, West Trenton, New Jersey, 2018}

By Alex R. Fiore and Pierre J. Lacombe

Prepared in cooperation with the U.S. Navy

Open-File Report 2020-1016 


\title{
U.S. Department of the Interior \\ DAVID BERNHARDT, Secretary
}

\author{
U.S. Geological Survey \\ James F. Reilly II, Director
}

U.S. Geological Survey, Reston, Virginia: 2020

For more information on the USGS - the Federal source for science about the Earth, its natural and living resources, natural hazards, and the environment—visit https://www.usgs.gov or call 1-888-ASK-USGS.

For an overview of USGS information products, including maps, imagery, and publications, visit https://store.usgs.gov/.

Any use of trade, firm, or product names is for descriptive purposes only and does not imply endorsement by the U.S. Government.

Although this information product, for the most part, is in the public domain, it also may contain copyrighted materials as noted in the text. Permission to reproduce copyrighted items must be secured from the copyright owner.

Suggested citation:

Fiore, A.R., and Lacombe, P.J., 2020, Groundwater levels and generalized potentiometric surfaces, former Naval Air Warfare Center, West Trenton, New Jersey, 2018: U.S. Geological Survey Open-File Report 2020-1016, 28 p., https://doi.org/10.3133/ofr20201016.

Associated data for this publication:

Fiore, A.R., 2020, Reported groundwater levels and groundwater pump-and-treat withdrawals, former Naval Air Warfare Center, West Trenton, New Jersey, 2018: U.S. Geological Survey data release https://doi.org/10.5066/P98N1GWV.

ISSN 2331-1258 (online) 


\section{Contents}

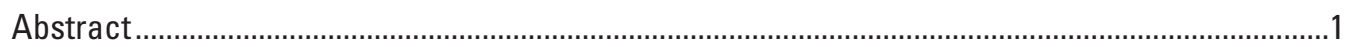

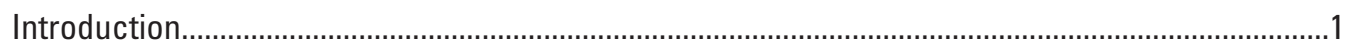

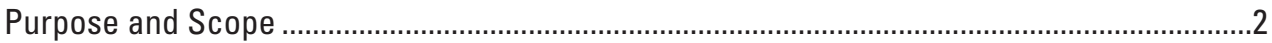

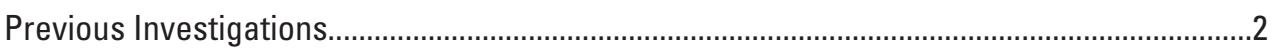

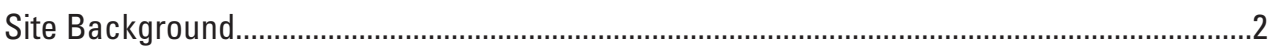

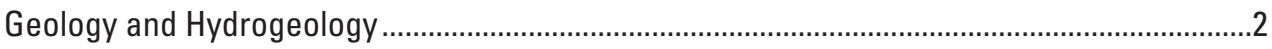

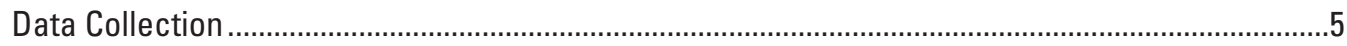

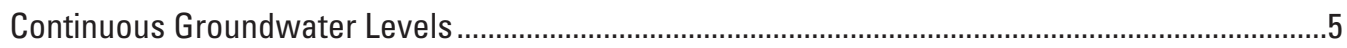

Groundwater-Level Fluctuations Caused by Seasonal Changes...............................................

Groundwater-Level Fluctuations Caused by Precipitation .........................................................

Groundwater-Level Fluctuations Caused by Pump-and-Treat (P\&T) Wells..............................6

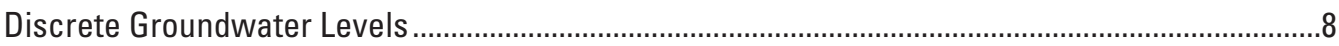

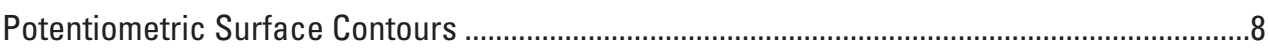

Potentiometric Surface Maps .............................................................................................14

Groundwater Levels and Vertical Flow Directions in Dip-Aligned Sections ..........................17

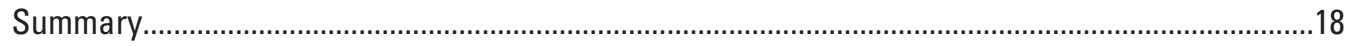

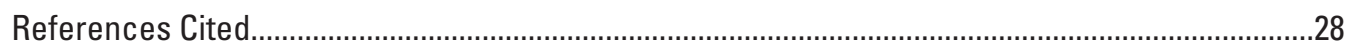

\section{Figures}

1. Well locations at the former Naval Air Warfare Center, West Trenton, New Jersey .......3

2. Conceptual geologic cross section, upper 250 feet underlying the former Naval Air Warfare Center, West Trenton, New Jersey..

3. Hydrographs of daily mean groundwater levels with hyetograph of daily total precipitation (top), and hydrographs of daily mean groundwater levels with daily pump-and-treat withdrawal volume (bottom), 2018 .

4. Groundwater levels, water-level potentiometric-surface contours, and groundwater-flow directions in the saprolite and fill, June 2018

5. Generalized water-level potentiometric-surface contours and generalized groundwater-flow directions in fractured bedrock at an altitude of approximately 100 feet above the North American Vertical Datum of 1988, June 2018

6. Groundwater levels in wells, generalized water-level potentiometric-surface contours, and generalized flow-direction components in the dip direction, Section A-A'

7. Groundwater levels in wells, generalized water-level potentiometric-surface contours, and generalized flow-direction components in the dip direction, Section B-B'.....

8. Groundwater levels in wells, generalized water-level potentiometric-surface contours, and generalized flow-direction components in the dip direction, Section C-C'.

9. Groundwater levels in wells, generalized water-level potentiometric-surface contours, and generalized flow-direction components in the dip direction, Section D-D'. 
10. Groundwater levels in wells, generalized water-level potentiometric-surface contours, and generalized flow-direction components in the dip direction,

Section E-E'

11. Groundwater levels in wells, generalized water-level potentiometric-surface contours, and generalized flow-direction components in the dip direction,

Section F-F'

12. Groundwater levels in wells, generalized water-level potentiometric-surface contours, and generalized flow-direction components in the dip direction, Section G-G'.

13. Groundwater levels in wells, generalized water-level potentiometric-surface contours, and generalized flow-direction components in the dip direction, Section $\mathrm{H}-\mathrm{H}^{\prime}$......

14. Groundwater levels in wells, generalized water-level potentiometric-surface contours, and generalized flow-direction components in the dip direction, Section I-I.

\section{Tables}

1. Well information and synoptic groundwater level data, former Naval Air Warfare Center and vicinity, West Trenton, New Jersey, June 18, 2018.

\section{Conversion Factors}

U.S. customary units to International System of Units

\begin{tabular}{|c|c|c|}
\hline Multiply & By & To obtain \\
\hline \multicolumn{3}{|c|}{ Length } \\
\hline inch (in.) & 2.54 & centimeter $(\mathrm{cm})$ \\
\hline inch (in.) & 25.4 & millimeter $(\mathrm{mm})$ \\
\hline foot (ft) & 0.3048 & meter $(\mathrm{m})$ \\
\hline mile (mi) & 1.609 & kilometer $(\mathrm{km})$ \\
\hline \multicolumn{3}{|c|}{ Area } \\
\hline acre & 4,047 & square meter $\left(\mathrm{m}^{2}\right)$ \\
\hline acre & 0.4047 & hectare (ha) \\
\hline acre & 0.4047 & square hectometer $\left(\mathrm{hm}^{2}\right)$ \\
\hline acre & 0.004047 & square kilometer $\left(\mathrm{km}^{2}\right)$ \\
\hline \multicolumn{3}{|c|}{ Volume } \\
\hline gallon (gal) & 3.785 & liter $(\mathrm{L})$ \\
\hline gallon (gal) & 0.003785 & cubic meter $\left(\mathrm{m}^{3}\right)$ \\
\hline gallon (gal) & 3.785 & cubic decimeter $\left(\mathrm{dm}^{3}\right)$ \\
\hline \multicolumn{3}{|c|}{ Transmissivity } \\
\hline foot squared per day $\left(\mathrm{ft}^{2} / \mathrm{d}\right)$ & 0.09290 & meter squared per day $\left(\mathrm{m}^{2} / \mathrm{d}\right)$ \\
\hline
\end{tabular}




\section{Datum}

Vertical coordinate information is referenced to the North American Vertical Datum of 1988 (NAVD 88).

Horizontal coordinate information is referenced to the North American Datum of 1983 (NAD 83).

Altitude, as used in this report, refers to distance above the vertical datum.

\section{Abbreviations}

$\begin{array}{ll}\text { BLS } & \text { below land surface } \\ \text { gal } & \text { gallon } \\ \text { lidar } & \text { light detection and ranging } \\ \text { NAWC } & \text { Naval Air Warfare Center } \\ \text { P\&T } & \text { pump-and-treat } \\ \text { PFAS } & \text { per- and polyfluoroalkyl substances } \\ \text { USGS } & \text { U.S. Geological Survey } \\ \text { VOC } & \text { volatile organic compound }\end{array}$





\title{
Groundwater Levels and Generalized Potentiometric Surfaces, Former Naval Air Warfare Center, West Trenton, New Jersey, 2018
}

\author{
By Alex R. Fiore and Pierre J. Lacombe
}

\section{Abstract}

Groundwater-level conditions, generalized groundwater potentiometric surfaces, and generalized flow directions at the decommissioned Naval Air Warfare Center in West Trenton, New Jersey, were evaluated for calendar year 2018. Groundwater levels measured continuously in five on-site wells and one nearby off-site well were plotted as hydrographs for January 1, 2018, through December 31, 2018. Groundwater levels measured in 110 wells on June 18, 2018, were contoured as generalized potentiometric surfaces on maps and sections. Generalized groundwater-flow directions inferred from the June 2018 data are shown in the maps and sections.

Groundwater levels in six monitoring wells fluctuated in response to seasonal changes, precipitation, and pumping from "pump-and-treat" (P\&T) wells. Record high precipitation totals in November, combined with a shutdown of three P\&T wells in November, resulted in annual high water levels in late November for five of the six wells monitored. Annual high groundwater levels that occur during the fall are uncharacteristic of the typical timing of annual high water levels, which usually occur in the spring following low evapotranspiration during the winter months, compared to annual low water levels, which usually occur in fall because of high evapotranspiration during the summer months. The annual high water levels occurred following a 3-day precipitation event totaling 3.50 inches from November 24-26, which also caused the largest 1-day water-level increase for five of the six wells in 2018.

The groundwater-level contour maps and sections include generalized flow directions. Given the heterogeneity of the site's fractured rock aquifers, contours and associated groundwater-flow directions shown on the maps and sections should be considered as broad conceptualizations. A nearly vertical fault striking southwest to northeast separates the northwestern part of the site underlain by the Lockatong Formation from the southeastern part, which is underlain by the Stockton Formation. In the Lockatong Formation, general groundwater-flow directions were toward P\&T wells. The P\&T wells limited the flow of groundwater in the Lockatong Formation from the site into the adjacent areas and contained most groundwater contamination within the site. A groundwater divide bisected the site; groundwater in the western part generally flowed to P\&T wells 8BR, 15BR, 20BR, 29BR, $56 \mathrm{BR}, 91 \mathrm{BR}$, and $\mathrm{BRP}-2$, and groundwater in the eastern part generally flowed to P\&T well 48BR. A groundwater divide also was present in the Stockton Formation. Groundwater west of the divide in the Stockton Formation generally flowed toward P\&T well 22BR, and groundwater east of the divide generally flowed south and southeast, away from the site. Saprolite and fill from land surface to depths of 25 feet below land surface exhibit similar properties to those of porous media, and water levels in surficial wells were contoured using a porous media aquifer approach. Water levels in these surficial wells indicate that groundwater in the saprolite and fill flowed predominantly toward Gold Run and, to a lesser extent, the West Ditch spring that drains to Gold Run. In addition, some shallow groundwater was captured by the cone of depression in the fractured bedrock and was attributed to P\&T well 48BR.

\section{Introduction}

Groundwater levels were measured continuously in six monitoring wells at the former Naval Air Warfare Center (NAWC) and vicinity in West Trenton, New Jersey, from January 1, 2018, to December 31, 2018, and measured manually in 110 wells at NAWC on June 18, 2018. The U.S. Geological Survey (USGS) collects these data annually as part of the long-term management plan administered by the U.S. Navy to contain and remediate groundwater that is contaminated with volatile organic compounds (VOCs) and per- and polyfluoroalkyl substances (PFAS).

Daily-mean values of continuously monitored water levels are plotted as hydrographs, together with daily pumpand-treat (P\&T) plant groundwater withdrawal volumes and hyetographs of daily precipitation totals. Discrete water-level data are presented in maps, a table, and in sections that show generalized potentiometric surfaces and general directions of groundwater flow. 
The U.S. Navy maintains a network of 17 P\&T wells to control the movement of contamination off the site (fig. 1). Seven P\&T wells (4BR, 5BR, 16BR, 31S, 41BR, BRP-1, and WDW) were offline throughout 2018 and are considered to be monitoring wells in this report. The total daily withdrawal from 10 of the $17 \mathrm{P} \& \mathrm{~T}$ wells in 2018 ranged from 15,000 to 81,000 gallons (gal) (Koman Government Solutions, LLC, 2018). The pumps are designed to run continuously with periodic shutdowns for maintenance. The pumps also shut off during power outages, mechanical failures, and low water levels, or at the request of the USGS or other entities. Knowledge of water-level conditions helps the U.S. Navy determine appropriate locations and rates of pumping to optimize contaminant withdrawal and limit off-site movement of contaminated groundwater.

\section{Purpose and Scope}

The USGS prepares an annual report for the U.S. Navy describing groundwater conditions at the NAWC for that particular calendar year. This report describes groundwater levels collected at NAWC in 2018, generalized potentiometric surfaces constructed from the measured groundwater levels, and the interpreted flow directions from the potentiometric surfaces for the year 2018 .

\section{Previous Investigations}

Maps and sections of the potentiometric surface at the NAWC were produced by the USGS for most years from 1995 through 2017. Some of the maps and sections were published in USGS reports (Lacombe, 2000, 2018); most were in annual unpublished Administrative reports prepared for the U.S. Navy. Groundwater-flow directions based on measured water levels were simulated by Lewis-Brown and Rice (2002) and Lewis-Brown and others (2006). Tiedeman and others (2010, 2018) developed a groundwater-flow model that incorporated multiple high- and low-permeability beds, was calibrated to multiple well-shutdown tests, and simulated average groundwater-flow directions based on 2008 conditions.

\section{Site Background}

The NAWC is a 65 -acre former U.S. Navy facility located in West Trenton, Ewing Township, New Jersey. The site was commissioned in 1951, and the U.S. Navy ceased operations and closed the facility in 1998. The NAWC is currently bordered to the north and west by the Trenton-Mercer Airport, which owns parts of the former property. The remainder of the property is currently privately owned or owned by Ewing Township. A 48-unit residential complex is located in the southeast corner, east of the railroad tracks that run through the site.
During the U.S. Navy's tenure, the NAWC was primarily used to test the performance of military jet engines under various atmospheric conditions. These operations resulted in the contamination of the groundwater beneath the site with trichloroethylene, a toxic VOC. The main source area for VOCs was located around buildings 40 and 41 in the southwestern part of the site, with a secondary source area from a former sludge disposal area northeast of the jet fuel storage tanks (fig. 1) (International Technology Corporation, 1994).

The presence of PFAS at NAWC likely resulted from the use of aqueous film-forming foam for fire suppression and training activities at the site. PFAS was first sampled at NAWC in 2016, with the highest concentrations of PFAS found in the northeast in an area similar to the location of the secondary sources of VOCs (fig. 1) (TetraTech, 2018). This area is referred to as the "VOC and PFAS source area" in this report.

\section{Geology and Hydrogeology}

The hydrogeology at the NAWC was described by Lacombe (2000) and Lacombe and Burton (2010) and is summarized below. Strata identifiers for the Lockatong Formation are from Tiedeman and others (2018).

Bedrock geology at the NAWC consists of the Triassicage Lockatong Formation and underlying Stockton Formation of the Newark Basin (fig. 2). In general, strata in the Lockatong Formation dip about 25 degrees northwest with a strike of about N $65^{\circ}$ E. Strata in the Stockton Formation dip about 25 degrees northwest and strike about $\mathrm{N} 42^{\circ} \mathrm{E}$.

The Lockatong Formation is divided into red massive mudstone, light gray massive mudstone, dark gray laminated mudstone, and black fissile carbon-rich mudstone. The most transmissive units are the fractured black fissile mudstones, which are the primary water-bearing zones at the site. Individual black fissile mudstone units are identified herein using the prefix "BlkFis-" followed by a number (for example, unit BlkFis-233). High-permeability bedding-plane fractures in the black fissile units can extend for hundreds of yards (Tiedeman and others, 2018). Massive units contain fewer fractures, and generally behave hydraulically as leaky semi-confining units. The Lockatong Formation bedrock at the NAWC is less fractured at depths greater than 250 feet (ft) below land surface (BLS), and therefore yields little water (Lacombe and Burton, 2010).

The Stockton Formation is divided into white arkosic sandstone, red arkosic sandstone, and red shale. The Stockton Formation shale and sandstones are fractured but behave more homogeneously than the fractured water-bearing units of the Lockatong Formation. The Stockton Formation at the NAWC has not been studied as extensively as the Lockatong Formation; therefore, high-resolution hydrostratigraphy has not been delineated. Like the Lockatong Formation, the 


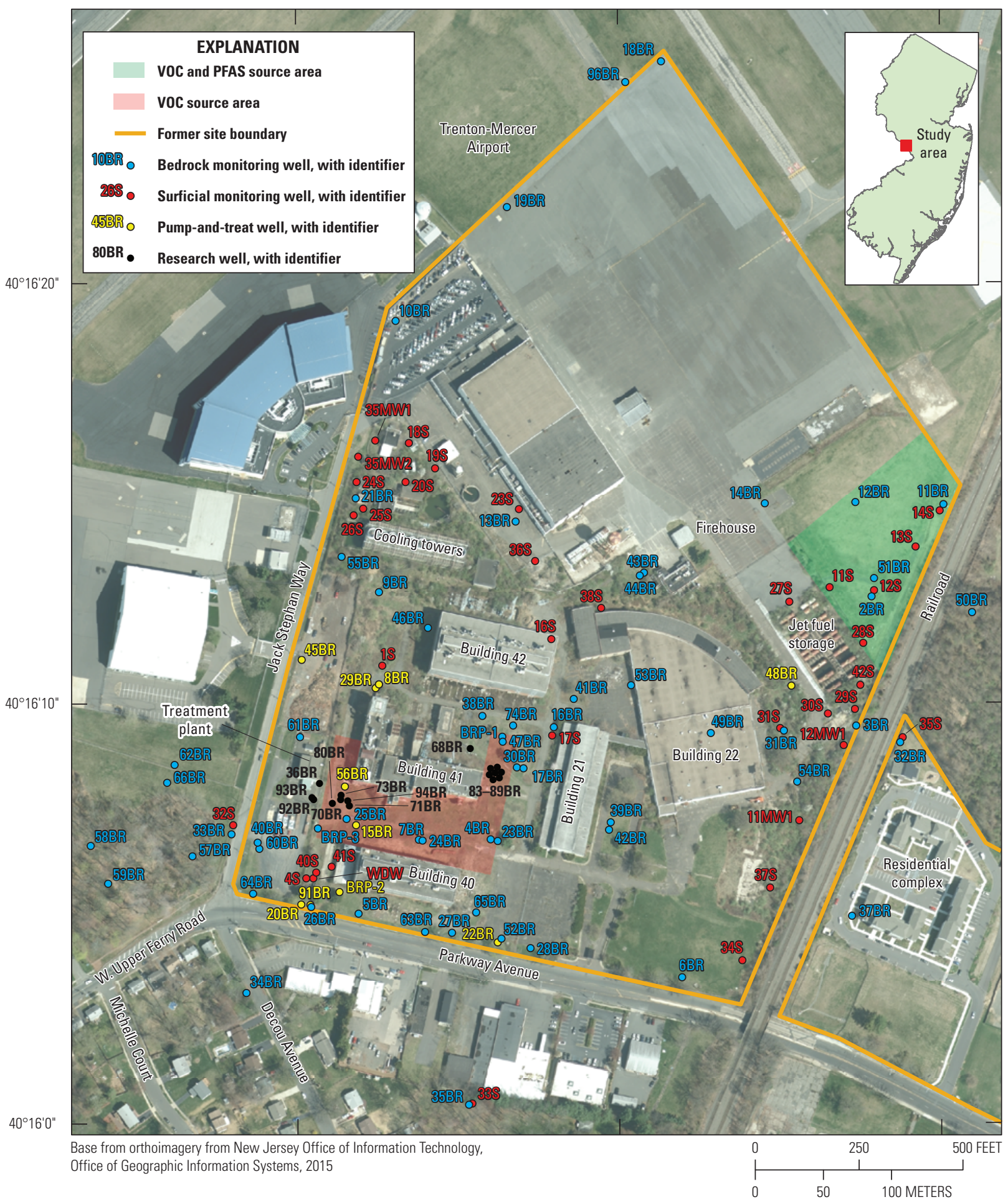

Figure 1. Well locations at the former Naval Air Warfare Center, West Trenton, New Jersey. [VOC, volatile organic compounds; PFAS, per- and polyfluoroalkyl substances] 
Stockton Formation at the NAWC is less fractured at depths of $250 \mathrm{ft}$ and greaand therefore has lower yields at those depths (Lacombe and Burton, 2010).

Bedrock of the Lockatong and Stockton Formations has weathered from land surface up to about $40 \mathrm{ft}$ BLS, creating a surficial zone consisting of unconsolidated saprolite to depths up to about $25 \mathrm{ft}$. In addition, up to $10 \mathrm{ft}$ of surficial material was removed and replaced with fill at selected locations at the site in the late 1990s. Much of the saprolite is fine-grained, but because it is unconsolidated, the saprolite can be represented more realistically as porous media than unweathered fractured bedrock for purposes of groundwater-flow assessment. A transitional weathered zone is present between the saprolite and the unweathered bedrock. Large fractures from the unweathered bedrock can extend into the weathered zone, but fractures also may be infilled with fine-grained sediment (Lacombe and Burton, 2010; Michalski and Britton, 1997). Thus, the transitional weathered zone can have groundwaterflow properties in common with both the saprolite and unweathered bedrock.

The Stockton Formation is separated from the Lockatong Formation by a near-vertical fault zone that strikes about $\mathrm{N} 65^{\circ} \mathrm{E}$ and dips more than $70^{\circ} \mathrm{SW}$ (Lacombe and Burton, 2010) (fig. 2). The fault zone, which consists of bedrock from the Lockatong and Stockton Formations, is a heterogeneous suite of discontinuous beds that dip in many different directions and whose attitude ranges from flat-lying to overturned. Most beds at depth along the fault are heavily brecciated and

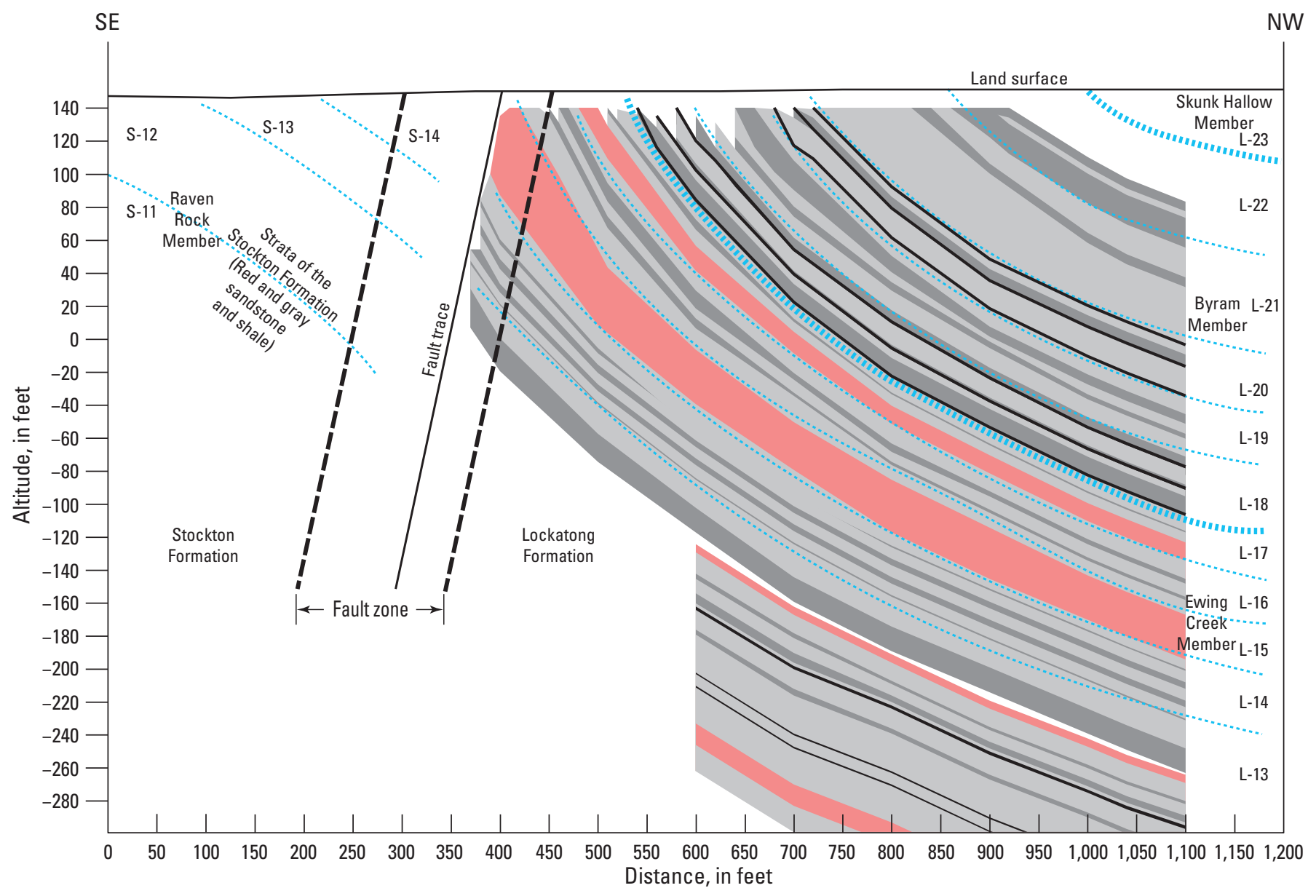

EXPLANATION

\begin{tabular}{llll}
\hline Lockatong Formation & & \\
Red massive mudstone & $\ldots . . .$. & Geophysical contacts \\
Light gray massive mudstone & $\ldots 1$ !In & Member division \\
Dark gray laminated mudstone & S-13 & $\begin{array}{c}\text { Stratum identifier (S, Stockton; } \\
\text { L, Lockatong) }\end{array}$ \\
\hline
\end{tabular}

Figure 2. Conceptual geologic cross section, upper 250 feet underlying the former Naval Air Warfare Center, West Trenton, New Jersey. (Modified from Lacombe and Burton [2010]). 
weathered to clay and behave as near-vertical confining units that limit groundwater flow between the Lockatong Formation and the Stockton Formation.

\section{Data Collection}

Precipitation data were obtained from the National Oceanographic and Atmospheric Administration weather station GHCND:USW00014792 at Trenton-Mercer Airport in West Trenton, New Jersey (accessed April 24, 2019, at https://www.ncdc.noaa.gov/cdo-web/datasets/GHCND/ stations/GHCND:USW00014792/detail.) NAWC is located less than 1 mile away from this weather station. Daily groundwater withdrawal volumes by the P\&T plant are reported by the U.S. Navy contractor (Koman Government Solutions, LLC, 2018) and are documented in a USGS data release (Fiore, 2020).

Continuous water-level data were obtained by installing digital recorders that use floats or pressure transducers on 11 on-site monitoring wells: 1S, 6BR, 16BR, 17BR, 30BR, 33BR, 38BR, 41BR, 58BR, BRP-1, and BRP-3, and 1 off-site monitoring well, Civil Defense Obs, located about 1.1 miles west of NAWC. Only data from wells 17BR, 33BR, 38BR, $58 \mathrm{BR}$, and BRP-3 are presented in this report. Water-level data from the other wells are available in the USGS National Water Information System database ((NWIS); U.S. Geological Survey, 2019). Water levels were recorded at 15 -minute intervals. Recorders in the on-site continuously monitored wells were removed during the period from June 27 through July 28 during water-quality sampling.

Discrete water levels were measured in 110 wells on June 18, 2018, by the USGS and a U.S. Navy contractor (Koman Government Solutions, LLC). Water levels were measured with electric or steel tapes with a repeatability of 0.01 $\mathrm{ft}$. Each tape used by the USGS was calibrated at the USGS Hydrologic Instrumentation Facility at the Stennis Space Center in Mississippi. The electric tape used by the U.S. Navy contractor measured within $0.03 \mathrm{ft}$ of a calibrated USGS electric tape (Fiore, 2020). Wells 33S, 35BR, and 45BR were not measured in 2018 because of access issues. Wells 12-MW-1, 19S, and 36S could not be field-located in 2018, so they were not measured. Well 7BR was not measured because the USGS was conducting a research experiment in this well at the time, making 7BR inaccessible. Wells 68BR, 71BR, 83BR, 84BR, 85BR, 86BR, 87BR, 88BR, 89BR, 92BR, 93BR, and 94BR were not measured because these are research wells (fig. 1) with long open intervals (table 1; Fiore, 2019). Discrete water-level measurements made by the USGS are archived in the NWIS database (U.S. Geological Survey, 2019). Waterlevel measurements reported by the U.S. Navy contractor and the associated data processing by the USGS are documented in a USGS data release (Fiore, 2020).

\section{Continuous Groundwater Levels}

Water-level hydrographs, hyetographs of daily precipitation totals, and daily groundwater withdrawal volumes by the P\&T plant for 2018 (fig. 3) for wells 17BR, 33BR, 38BR, 58BR, BRP-3, and Civil Defense Obs show fluctuations that resulted from seasonal variations, precipitation events, and withdrawal changes at P\&T wells (fig.3). Continuous water levels were collected at 15-minute intervals, but the daily mean water level for each well is plotted on the hydrographs. The discrete water-level measurements collected on June 18, 2018, also are plotted. Measurements from Civil Defense Obs are included only for comparison purposes to on-site wells and to show nearby fluctuations when site data were missing. Data from this well are not discussed further.

\section{Groundwater-Level Fluctuations Caused by Seasonal Changes}

Seasonal water-level fluctuations were atypical for NAWC in 2018. The Trenton area experienced its wettest year on record since 1889 with 62.35 inches (in.) of precipitation. The November precipitation total of 8.24 in. at the TrentonMercer Airport weather station was the highest November total on record for the area (Office of the New Jersey State Climatologist, 2018). Given the record-high amount of precipitation in November, the annual high and low water levels at NAWC occurred during uncharacteristic times of the year.

Annual high water levels in wells 17BR, 33BR, 58BR, BRP-3, and Civil Defense Obs occurred on November 24-26, 2018 , which was likely related to the record amount of precipitation in November. Typically, annual high water levels occur in the spring in response to the low evapotranspiration (ET) that occurs throughout the winter. The annual high water level measured in well 38BR was the discrete measurement made during the synoptic event in June. Low P\&T withdrawals during November also likely contributed to high November water levels but to a lesser degree than the record precipitation totals. Water levels were increasing in 33BR and BRP-3 at the time recorders were pulled from the wells in June and July, so there is a possibility the annual high water levels in those wells occurred during this time, but this assumption cannot be verified as no continuous data are available from this time period. Water levels in nearby well Civil Defense Obs, which is outside the influence of the P\&T wells, did not increase during the period from June through July, and the annual high still occurred in November. Wells 17BR and 58BR had decreasing water levels at the time recorders were removed, so it is unlikely that the annual high occurred earlier than November in these on-site wells.

Annual low water levels at the NAWC occurred around January 11, 2018, in wells 17BR, 38BR, BRP-3, and Civil Defense Obs, on September 6 in well 58BR, and on September 8 in well 33BR. Annual low water levels usually occur in the fall in response to high ET that occurs throughout 
the summer. The January 2018 annual low water levels in 17BR, 38BR, BRP-3, and Civil Defense Obs likely resulted from the below-average precipitation that had been ongoing since November 2017 (Office of the New Jersey State Climatologist, 2018). Similarly, the September 2018 annual low water levels in 33BR and 58BR likely resulted from the below-average precipitation in August. Despite the 9-month difference in timing of the annual lows, the January water levels were within about $0.1 \mathrm{ft}$ or less of those water levels measured in September in each well except 38BR, making the difference negligible. The water-level responses in well 38BR to seasonal changes and longer-term weather events were greater than the responses to precipitation, likely because of the low transmissivity of the surrounding aquifer materials (Fiore, 2014). So, the dry conditions in late 2017 had more of an overall effect on the water level in well 38BR compared to the other wells.

\section{Groundwater-Level Fluctuations Caused by Precipitation}

A storm on January 12-13, 2018, produced 1.25 in. of precipitation causing water levels in 17BR, 33BR, 38BR, 58BR, BRP-3, and Civil Defense Obs to rise from their annual lows (and 33BR and 58BR from winter seasonal lows), which occurred on January 11, 2018. The water level in well 17BR increased about $1.2 \mathrm{ft}$ in 3 days, well 33BR increased about $1.9 \mathrm{ft}$ in 6 days, well 58BR increased about $0.7 \mathrm{ft}$ in 4 days, well BRP-3 increased about $1.8 \mathrm{ft}$ in 6 days, and well Civil Defense Obs increased about $2.1 \mathrm{ft}$ in 7 days. The low transmissivity of the aquifer materials around well 38BR (Fiore, 2014) caused a more gradual, less sensitive response to precipitation as well as a longer recovery time, which prevented water levels in well 38BR from responding similarly to wells intersecting fractures with higher transmissivity.

The month of February 2018 had the fourth highest precipitation total for any February on record for the Trenton area, with 5.75 in. (Office of the New Jersey State Climatologist, 2018). More than half that total occurred in an 8-day period from February 4-11, with 3.22 in. of precipitation. Water levels increased about $0.8 \mathrm{ft}$ in $17 \mathrm{BR}$, about $1.6 \mathrm{ft}$ in 38BR, and more than $2 \mathrm{ft}$ in wells 33BR, 58BR, and BRP-3 in February.

Water levels in wells 17BR, 33BR, 58BR, BRP-3, and Civil Defense Obs peaked to winter highs around March 3, following 1.85 in. of precipitation on March 1-2, which increased water levels by about $0.7 \mathrm{ft}$ in well 17BR, about $0.9 \mathrm{ft}$ in 33BR, and about $0.8 \mathrm{ft}$ in 58BR and BRP-3. Shortly thereafter, on March 7, a total of 1.61 in. of precipitation caused less than $0.3 \mathrm{ft}$ of water-level increase in those four wells, which indicates that high-precipitation storms of long duration cause greater recharge at NAWC than high-precipitation storms of shorter duration. Water levels in well 38BR varied within $0.1 \mathrm{ft}$ throughout the month and indicated no response to storms.
The month of May 2018 had the third highest precipitation total for any May on record for the Trenton area, with 7.22 in. (Office of the New Jersey State Climatologist, 2018). The largest daily precipitation event in 2018 resulted from a storm on May 27 that produced 2.79 in. of precipitation. This storm occurred 3 days before recorders were removed for sampling, so the overall water-level response to this storm was not measured. Manual measurements on June 18 and the downward trending hydrographs for 17BR, 58BR, and Civil Defense Obs indicate a return toward normal seasonal levels. Water levels were rising in wells 33BR and BRP-3 at the time the recorders were pulled, but the manual data on June 18 and recovery in 17BR, 58BR, and Civil Defense Obs indicated recovery was also likely in wells 33BR and BRP-3.

The largest 3-day precipitation total in 2018 was 3.50 in., which occurred from November 24-26. On November 26, this storm also produced the greatest 1-day water-level increase in 2018 in all wells except well 38BR; the water level in well 17BR increased about $1.0 \mathrm{ft}$, water levels in 33BR and 58BR increased about $1.4 \mathrm{ft}$, and the water level in BRP-3 increased about $1.3 \mathrm{ft}$ to annual high water levels. The water level in well $38 \mathrm{BR}$ did not respond to this precipitation event, and never increased more than $0.04 \mathrm{ft}$ in 1 day throughout 2018.

The longest periods without substantial precipitation in 2018 were July 7-14, August 23-September 7, and December 3-13. The August dry period decreased water levels to the seasonal summer lows in 17BR, 38BR, and BRP-3, and annual lows in 33B and 58BR, before increased precipitation in early September raised water levels. The December dry period resulted in decreased water levels in each well from annual highs to pre-November storm levels.

\section{Groundwater-Level Fluctuations Caused by Pump-and-Treat (P\&T) Wells}

During 2018, the P\&T wells were off for short periods to conduct maintenance, to accommodate research, or because of equipment failure or power loss. A power failure caused a treatment plant instrument malfunction in September through early October and the loss of P\&T withdrawal data (Koman Government Solutions LLC, 2018). Non-pumping periods affected water levels in monitoring wells. Short-term variations in water levels resulting from precipitation patterns can be difficult to distinguish from short-term water-level variations resulting from $\mathrm{P} \& \mathrm{~T}$ well pumping rate changes (Lacombe, 2018).

Water levels in wells 38BR, 58BR, and BRP-3 have been shown to respond directly to P\&T well 15BR (Lacombe, 2000; Tiedeman and others, 2010). Well 15BR had high pumping rates in January through April (Koman Government Solutions, LLC, 2018) and produced a large portion of the total withdrawal volume to the P\&T plant. The higher withdrawals in January and February from P\&T well 15BR likely contributed to the lowered water levels observed in wells 38BR, $58 \mathrm{BR}$, and BRP-3 at that time, in combination with the low 


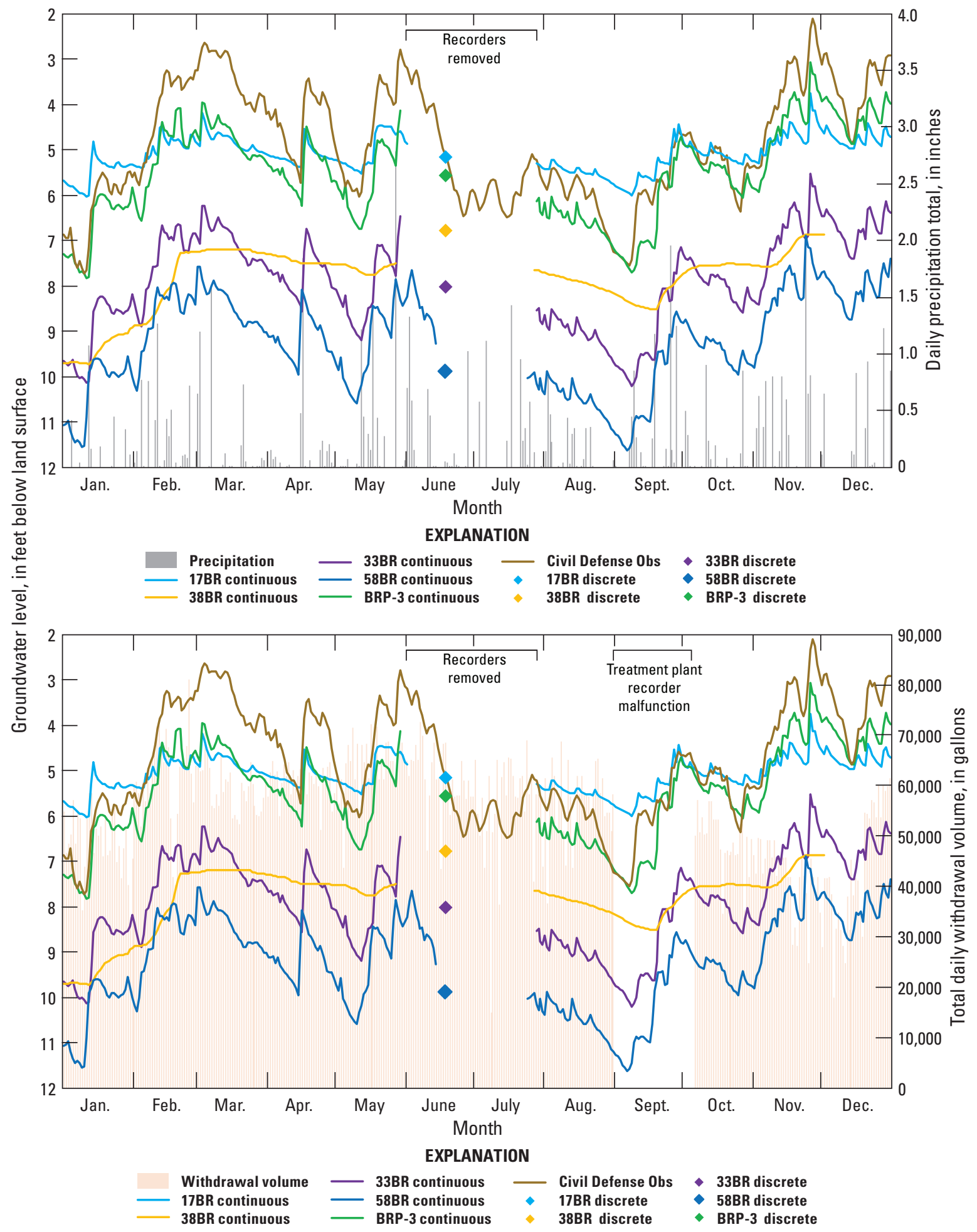

Figure 3. Hydrographs of daily mean groundwater levels with hyetograph of daily total precipitation (top), and hydrographs of daily mean groundwater levels with daily pump-and-treat withdrawal volume (bottom), 2018. Civil Defense Obs groundwater levels have been shifted 10 feet shallower. 
precipitation observed in late 2017 (Office of the New Jersey State Climatologist, 2018). Well 33BR showed a response similar to that in well 58BR, which indicates that 33BR also may be sensitive to pumping at P\&T well 15BR.

On February 1, the total withdrawal volume from the P\&T wells increased to about 60,000 gal from an average of less than 40,000 gal the previous 3 days. Over the subsequent 3 days, water levels decreased minimally in wells 33BR, 58BR, and BRP-3. Wells 17BR, 38BR, and off-site well Civil Defense Obs. Well Civil Defense Obs is outside the influence of the P\&T wells at NAWC and generally has approximately the same magnitude of water-level fluctuations as wells 33BR, 58BR, and BRP-3, which indicates the water level decreases in the on-site wells were likely the result of the increased withdrawals from the P\&T wells.

Water levels in wells 33BR, 58BR, and BRP-3 have been shown to respond directly to P\&T well 45BR (Tiedeman and others, 2010). P\&T well 45BR was offline because of equipment failure from February to April (Koman Government Solutions, LLC, 2018). This likely contributed to the higher water levels observed in those wells during this period. When P\&T well 45BR resumed operation on April 19 (Koman Government Solutions, LLC, 2018), water levels in these wells increased by about $2 \mathrm{ft}$ or more over the next 24 days. Well 45BR is open to the black fissile mudstone unit BlkFis-233 and possibly unit BlkFis-246, whereas wells 33BR, 58BR, and BRP-3 are open to stratigraphically higher units. The shallower depths of wells 33BR and BRP-3 locate their open intervals in a transitional semi-weathered zone where horizontal groundwater flow dominates rather than flow along bedding planes (Tiedeman and others, 2010).

\section{Discrete Groundwater Levels}

Discrete water levels (table 1) were used to construct potentiometric surface contour maps and sections. Because $\mathrm{P} \& \mathrm{~T}$ wells were in operation during these measurements, the potentiometric surface contours represent a stressed hydrologic condition. The stressed condition is the typical operational condition and the unstressed condition is atypical; the P\&T system creates stressed hydrologic conditions to remove contaminants from the aquifer and to limit contaminant migration off-site (EA Engineering, Science, and Technology, Inc., 2000).

\section{Potentiometric Surface Contours}

Contouring water levels in fractured rock aquifers by using the traditional porous media assumption is only partly realistic because of the high heterogeneity of groundwater flow through fractures. The flow directions are based on the geometry and connectivity of fractures and the resulting anisotropy in average transmissivity, which cannot be properly represented without numerical groundwater-flow modeling (Tiedeman and others, 2018). The potentiometric contours in the Lockatong Formation in the series of maps and cross sections presented herein are based on the methods of Lacombe $(2000,2018)$. For cross sections, the method consists of drawing contour lines perpendicular to waterbearing black fissile mudstone units, so groundwater flow occurs along bedding planes parallel to the strike and (or) dip of the units. This method provides a generalized conceptualization of groundwater-flow directions, and so, the specific hydraulic gradients calculated between any two given points should not be considered an accurate representation of the flow direction. Although the Stockton Formation is a fractured rock aquifer, available information regarding fracture geometry or high-resolution water-bearing units is too limited to justify use of the above method; therefore, in this report, the Stockton Formation is contoured as a porous medium based on the more homogenous nature of groundwater flow in the Stockton Formation compared to the Lockatong Formation (Lacombe, 2000).

The surficial saprolite is mostly unconsolidated and was contoured as a porous medium. The resulting potentiometric surface can be assumed to be reasonably realistic. Although the saprolite is hydraulically connected to bedrock fractures through the transitional weathered zone, water levels in the saprolite were contoured separately due to this difference in flow properties. This conceptual model corresponds to the "leaky multiunit aquifer system" of Michalski and Britton (1997). However, the transitional weathered zone is assumed to have a flow regime more similar to the underlying unweathered bedrock than the overlying saprolite, so water levels from all wells open to the weathered zone are contoured with the bedrock rather than the saprolite; only water levels in wells designated with the letter suffix "S" (fig. 4) were used to develop the potentiometric surface contours in the saprolite. The only exception is well 70BR-10, which is open to the weathered zone and contoured with the bedrock and the saprolite because of its shallow depth and location in the VOC source area (fig. 4) where few saprolite-screened wells currently exist. Wells 11-MW-1, 35-MW-1, and 35-MW-2 are also surficial wells open to saprolite despite not having an "S" designation.

Potentiometric contours in the bedrock units terminate at the fault, which is conceptualized as a low-permeability barrier to groundwater flow that restricts groundwater between the Lockatong Formation and the Stockton Formation. Because the fault zone, like the bedrock, is weathered near land surface, the shallow fault zone is not a hydraulic barrier in the saprolite. As a result, the fault is not shown on the maps of water levels in the saprolite, and water levels in wells on both sides of the fault were used in contouring.

Gold Run spring occurs west of the NAWC perimeter near the intersection of Parkway Avenue, Jack Stephan Way, and West Upper Ferry Road (figs. 1,4). This spring feeds the ancestral West Branch of Gold Run, a southeast-flowing stream currently inside a culvert underneath Parkway Avenue. Lacombe $(2000,2018)$ contoured groundwater levels around 
Table 1. Well information and synoptic groundwater level data, former Naval Air Warfare Center and vicinity, West Trenton, New Jersey, June 18, 2018.

[NWIS, U.S. Geological Survey National Water Information System; ft, feet; NAVD 88, National Vertical Datum of 1988; CDO, Civil Defense Obs; WDW, West Ditch Well; M, monitoring; P\&T, pump-andtreat; R, research; Su, surficial; L, Lockatong Formation bedrock; St, Stockton Formation bedrock; --, none; nm, not measured; <, water level is below bottom of open interval; U, U.S. Geological Survey; C, U.S. Navy contractor]

\begin{tabular}{|c|c|c|c|c|c|c|c|c|c|c|}
\hline Well name & NWIS site number & $\begin{array}{l}\text { Well } \\
\text { type }\end{array}$ & Hydrogeologic unit & $\begin{array}{l}\text { Line of } \\
\text { section }\end{array}$ & $\begin{array}{l}\text { Open inter- } \\
\text { val depth, } \\
\text { in ft }\end{array}$ & $\begin{array}{c}\text { Land- } \\
\text { surface } \\
\text { altitude, } \\
\text { in ft NAVD88 }\end{array}$ & $\begin{array}{c}\text { Water- } \\
\text { level } \\
\text { depth, in ft }\end{array}$ & $\begin{array}{c}\text { Water-level } \\
\text { altitude, } \\
\text { in ft NAVD } \\
88\end{array}$ & $\begin{array}{c}\text { Measurement } \\
\text { agency }\end{array}$ & $\begin{array}{l}\text { Recorder } \\
\text { installed }\end{array}$ \\
\hline $1 \mathrm{~S}$ & 401611074484901 & M & $\mathrm{Su}$ & -- & $3-13$ & 150.02 & 4.74 & 145.28 & $\mathrm{U}$ & Yes \\
\hline $2 \mathrm{BR}$ & 401612074483401 & M & $\mathrm{L}$ & B-B' & $40-60$ & 157.48 & 8.58 & 148.90 & $\mathrm{C}$ & No \\
\hline $3 \mathrm{BR}$ & 401609074483402 & M & St & B-B' & $35-45$ & 156.54 & 9.13 & 147.41 & $\mathrm{C}$ & No \\
\hline 4BR & 401606074484502 & M & $\mathrm{L}$ & F-F' & $24-39$ & 149.95 & 6.10 & 143.85 & $\mathrm{U}$ & No \\
\hline $4 \mathrm{~S}$ & 401605074485102 & M & $\mathrm{Su}$ & -- & $3-7$ & 149.03 & dry & $<142.03$ & $\mathrm{C}$ & No \\
\hline $5 \mathrm{BR}$ & 401605074484901 & M & $\mathrm{L}$ & H-H' & $69-84$ & 148.73 & 7.76 & 140.97 & $\mathrm{U}$ & No \\
\hline $6 \mathrm{BR}$ & 401603074483901 & M & St & E-E' & $52-77$ & 142.71 & 3.36 & 139.35 & $\mathrm{U}$ & Yes \\
\hline 7BR & 401606074484802 & $\mathrm{M}$ & $\mathrm{L}$ & G-G' & $38-53$ & 148.95 & $\mathrm{~nm}$ & $\mathrm{~nm}$ & $\mathrm{U}$ & No \\
\hline $8 \mathrm{BR}$ & 401610074484901 & P\&T & $\mathrm{L}$ & G-G' & $32-57$ & 150.50 & 17.12 & 133.38 & $\mathrm{U}$ & No \\
\hline 9BR & 401612074484901 & $\mathrm{M}$ & $\mathrm{L}$ & G-G' & $19-44$ & 151.89 & 2.02 & 149.87 & $\mathrm{U}$ & No \\
\hline $10 \mathrm{BR}^{1}$ & 401619074484801 & M & $\mathrm{L}$ & -- & $63-88$ & 167.81 & 10.59 & 157.22 & $\mathrm{C}$ & No \\
\hline $11 \mathrm{BR}$ & 401614074483101 & M & $\mathrm{L}$ & A-A' & $55-75$ & 163.42 & 14.57 & 148.85 & $\mathrm{C}$ & No \\
\hline 11-MW-1 & 401607074483601 & M & $\mathrm{Su}$ & -- & $8-22$ & 155.38 & 12.37 & 143.01 & $\mathrm{U}$ & No \\
\hline $11 \mathrm{~S}$ & 401612074483501 & M & $\mathrm{Su}$ & -- & $8-23$ & 158.79 & 9.27 & 149.52 & $\mathrm{C}$ & No \\
\hline 12BR & 401614074483401 & M & $\mathrm{L}$ & B-B' & $56.5-71.5$ & 162.11 & 13.72 & 148.39 & $\mathrm{C}$ & No \\
\hline 12-MW-1 & 401609074483303 & M & $\mathrm{Su}$ & -- & $5-15$ & 155.44 & $\mathrm{~nm}$ & $\mathrm{~nm}$ & $\mathrm{~nm}$ & No \\
\hline $12 \mathrm{~S}$ & 401612074483301 & M & $\mathrm{Su}$ & -- & $10.5-20.5$ & 156.28 & 8.38 & 147.90 & $\mathrm{C}$ & No \\
\hline $13 \mathrm{BR}$ & 401614074484502 & M & $\mathrm{L}$ & E-E' & 48-63 & 170.22 & 20.84 & 149.38 & $\mathrm{C}$ & No \\
\hline $13 \mathrm{~S}$ & 401613074483201 & M & $\mathrm{Su}$ & -- & $10-20$ & 158.21 & 8.66 & 149.55 & $\mathrm{C}$ & No \\
\hline 14BR & 401614074483701 & M & $\mathrm{L}$ & $\mathrm{C}-\mathrm{C}^{\prime}$ & $42-67$ & 166.02 & 16.60 & 149.42 & $\mathrm{C}$ & No \\
\hline $14 \mathrm{~S}$ & 401614074483102 & $\mathrm{M}$ & $\mathrm{Su}$ & -- & $14.5-24.5$ & 163.21 & 13.02 & 150.19 & $\mathrm{C}$ & No \\
\hline $15 \mathrm{BR}$ & 401607074485002 & P\&T & $\mathrm{L}$ & H-H' & $26-41$ & 148.81 & 10.07 & 138.74 & $\mathrm{U}$ & No \\
\hline $16 \mathrm{BR}$ & 401609074484302 & $\mathrm{M}$ & $\mathrm{L}$ & E-E' & $40-65$ & 149.44 & 4.87 & 144.57 & $\mathrm{U}$ & Yes \\
\hline $16 \mathrm{~S}$ & 401611074484401 & M & $\mathrm{Su}$ & -- & $2-12$ & 149.21 & 3.73 & 145.48 & $\mathrm{U}$ & No \\
\hline $17 \mathrm{BR}$ & 401608074484401 & M & $\mathrm{L}$ & $\mathrm{F}-\mathrm{F}^{\prime}$ & $19-44$ & 149.41 & 5.17 & 144.24 & $\mathrm{U}$ & Yes \\
\hline $17 \mathrm{~S}$ & 401609074484301 & M & $\mathrm{Su}$ & -- & $3-8$ & 149.17 & 3.06 & 146.11 & $\mathrm{U}$ & No \\
\hline $18 \mathrm{BR}^{1}$ & 401625074484001 & M & $\mathrm{L}$ & -- & $27-52$ & 175.57 & 12.27 & 163.30 & $\mathrm{C}$ & No \\
\hline $18 \mathrm{~S}$ & 401616074484801 & M & $\mathrm{Su}$ & -- & $6-16$ & 169.05 & 12.01 & 157.04 & $\mathrm{U}$ & No \\
\hline
\end{tabular}


Table 1. Well information and synoptic groundwater level data, former Naval Air Warfare Center and vicinity, West Trenton, New Jersey, June 18, 2018. - Continued

[NWIS, U.S. Geological Survey National Water Information System; ft, feet; NAVD 88, National Vertical Datum of 1988; CDO, Civil Defense Obs; WDW, West Ditch Well; M, monitoring; P\&T, pump-andtreat; R, research; Su, surficial; L, Lockatong Formation bedrock; St, Stockton Formation bedrock; --, none; nm, not measured; <, water level is below bottom of open interval; U, U.S. Geological Survey; C, U.S. Navy contractor]

\begin{tabular}{|c|c|c|c|c|c|c|c|c|c|c|}
\hline Well name & NWIS site number & $\begin{array}{l}\text { Well } \\
\text { type }\end{array}$ & Hydrogeologic unit & $\begin{array}{l}\text { Line of } \\
\text { section }\end{array}$ & $\begin{array}{l}\text { Open inter- } \\
\text { val depth, } \\
\text { in ft }\end{array}$ & $\begin{array}{c}\text { Land- } \\
\text { surface } \\
\text { altitude, } \\
\text { in ft NAVD88 }\end{array}$ & $\begin{array}{c}\text { Water- } \\
\text { level } \\
\text { depth, in ft }\end{array}$ & $\begin{array}{c}\text { Water-level } \\
\text { altitude, } \\
\text { in ft NAVD } \\
88\end{array}$ & $\begin{array}{c}\text { Measurement } \\
\text { agency }\end{array}$ & $\begin{array}{l}\text { Recorder } \\
\text { installed }\end{array}$ \\
\hline $19 \mathrm{BR}^{1}$ & 401621074484501 & $\mathrm{M}$ & $\mathrm{L}$ & -- & $43-58$ & 170.65 & 11.34 & 159.31 & $\mathrm{C}$ & No \\
\hline $19 \mathrm{~S}$ & 401615074484701 & M & $\mathrm{Su}$ & -- & $7-17$ & 168.83 & $\mathrm{~nm}$ & $\mathrm{~nm}$ & $\mathrm{~nm}$ & No \\
\hline 20BR & 401605074485103 & $\mathrm{P} \& \mathrm{~T}$ & $\mathrm{~L}$ & H-H' & $28-43$ & 149.70 & 9.33 & 140.37 & $\mathrm{U}$ & No \\
\hline $20 \mathrm{~S}$ & 401615074484801 & M & $\mathrm{Su}$ & -- & 4-19 & 168.55 & 11.67 & 156.88 & $\mathrm{U}$ & No \\
\hline $21 \mathrm{BR}^{1}$ & 401614074485002 & $\mathrm{M}$ & $\mathrm{L}$ & -- & $50-65$ & 167.91 & 12.02 & 155.89 & $\mathrm{U}$ & No \\
\hline 22BR & 401604074484501 & $\mathrm{P} \& \mathrm{~T}$ & St & F-F' & $24-49$ & 147.31 & 22.41 & 124.90 & $\mathrm{U}$ & No \\
\hline $23 \mathrm{BR}$ & 401606074484501 & $\mathrm{M}$ & $\mathrm{L}$ & F-F' & $65-90$ & 149.84 & 7.42 & 142.42 & $\mathrm{U}$ & No \\
\hline $23 \mathrm{~S}$ & 401614074484501 & M & $\mathrm{Su}$ & -- & $4-14$ & 169.74 & dry & $<155.74$ & $\mathrm{C}$ & No \\
\hline $24 \mathrm{BR}$ & 401606074484801 & M & $\mathrm{L}$ & $\mathrm{G}-\mathrm{G}^{\prime}$ & $80-95$ & 149.12 & 8.65 & 140.47 & $\mathrm{U}$ & No \\
\hline $24 \mathrm{~S}$ & 401615074485001 & M & $\mathrm{Su}$ & -- & $5.5-15.5$ & 168.29 & 11.61 & 156.68 & $\mathrm{U}$ & No \\
\hline $25 \mathrm{BR}$ & 401607074485001 & M & $\mathrm{L}$ & H-H' & $75-100$ & 148.45 & 5.90 & 142.55 & $\mathrm{C}$ & No \\
\hline $25 \mathrm{~S}$ & 401614074484901 & M & $\mathrm{Su}$ & -- & $3.5-18.5$ & 168.08 & 12.33 & 155.75 & $\mathrm{U}$ & No \\
\hline 26BR & 401605074485101 & M & $\mathrm{L}$ & H-H' & 80-95 & 149.41 & 7.33 & 142.08 & $\mathrm{U}$ & No \\
\hline $26 \mathrm{~S}$ & 401614074485001 & M & $\mathrm{Su}$ & -- & $6.3-16.3$ & 168.38 & 12.78 & 155.60 & $\mathrm{U}$ & No \\
\hline $27 \mathrm{BR}$ & 401604074484701 & M & $\mathrm{St}$ & G-G' & $65-80$ & 147.34 & 8.97 & 138.37 & $\mathrm{U}$ & No \\
\hline $27 \mathrm{~S}$ & 401612074483601 & M & $\mathrm{Su}$ & -- & $11.2-21.2$ & 161.27 & 12.13 & 149.14 & $\mathrm{C}$ & No \\
\hline 28BR & 401604074484401 & M & $\mathrm{St}$ & F-F' & 76-91 & 147.73 & 9.21 & 138.52 & $\mathrm{U}$ & No \\
\hline $28 \mathrm{~S}$ & 401611074483401 & $\mathrm{M}$ & $\mathrm{Su}$ & -- & $10-25$ & 156.42 & 9.05 & 147.37 & $\mathrm{C}$ & No \\
\hline 29BR & 401609074484901 & P\&T & $\mathrm{L}$ & G-G' & $85-100$ & 150.54 & 30.92 & 119.62 & $\mathrm{U}$ & No \\
\hline $29 \mathrm{~S}$ & 401609074483401 & M & $\mathrm{Su}$ & -- & $10-20$ & 156.29 & 7.12 & 149.17 & $\mathrm{C}$ & No \\
\hline 30BR & 401608074484501 & M & $\mathrm{L}$ & F-F' & $85-110$ & 149.53 & 7.57 & 141.96 & $\mathrm{U}$ & Yes \\
\hline $30 \mathrm{~S}$ & 401609074483501 & $\mathrm{M}$ & $\mathrm{Su}$ & -- & $7.5-17.5$ & 158.24 & 10.21 & 148.03 & $\mathrm{C}$ & No \\
\hline $31 \mathrm{BR}$ & 401609074483601 & M & St & $\mathrm{C}-\mathrm{C}^{\prime}$ & $35-45$ & 151.09 & 7.77 & 143.32 & $\mathrm{U}$ & No \\
\hline $31 \mathrm{~S}$ & 401609074483602 & M & $\mathrm{Su}$ & -- & $10-20$ & 150.89 & 7.44 & 143.45 & $\mathrm{U}$ & No \\
\hline $32 \mathrm{BR}$ & 401609074483301 & M & $\mathrm{S}$ & B-B' & $40-55$ & 154.02 & 8.92 & 145.10 & $\mathrm{C}$ & No \\
\hline $32 \mathrm{~S}$ & 401606074485301 & M & $\mathrm{Su}$ & -- & $5-15$ & 152.90 & 7.61 & 145.29 & $\mathrm{U}$ & No \\
\hline 33BR & 401607074485301 & M & $\mathrm{L}$ & $\mathrm{I}^{-\mathrm{I}^{\prime}}$ & $30-45$ & 152.46 & 8.02 & 144.44 & $\mathrm{U}$ & Yes \\
\hline $33 \mathrm{~S}$ & 401600074484601 & M & $\mathrm{Su}$ & -- & $6-16$ & 154.61 & $\mathrm{~nm}$ & $\mathrm{~nm}$ & $\mathrm{U}$ & No \\
\hline
\end{tabular}


Table 1. Well information and synoptic groundwater level data, former Naval Air Warfare Center and vicinity, West Trenton, New Jersey, June 18, 2018.-Continued

[NWIS, U.S. Geological Survey National Water Information System; ft, feet; NAVD 88, National Vertical Datum of 1988; CDO, Civil Defense Obs; WDW, West Ditch Well; M, monitoring; P\&T, pump-andtreat; R, research; Su, surficial; L, Lockatong Formation bedrock; St, Stockton Formation bedrock; --, none; nm, not measured; <, water level is below bottom of open interval; U, U.S. Geological Survey; C, U.S. Navy contractor]

\begin{tabular}{|c|c|c|c|c|c|c|c|c|c|c|}
\hline Well name & NWIS site number & $\begin{array}{l}\text { Well } \\
\text { type }\end{array}$ & Hydrogeologic unit & $\begin{array}{l}\text { Line of } \\
\text { section }\end{array}$ & $\begin{array}{l}\text { Open inter- } \\
\text { val depth, } \\
\text { in ft }\end{array}$ & $\begin{array}{c}\text { Land- } \\
\text { surface } \\
\text { altitude, } \\
\text { in ft NAVD88 }\end{array}$ & $\begin{array}{c}\text { Water- } \\
\text { level } \\
\text { depth, in ft }\end{array}$ & $\begin{array}{c}\text { Water-level } \\
\text { altitude, } \\
\text { in ft NAVD } \\
88\end{array}$ & $\begin{array}{l}\text { Measurement } \\
\text { agency }\end{array}$ & $\begin{array}{l}\text { Recorder } \\
\text { installed }\end{array}$ \\
\hline 34BR & 401603074485301 & M & $\mathrm{L}$ & $\mathrm{I}^{-\mathrm{I}^{\prime}}$ & $35-48$ & 150.02 & 8.03 & 141.99 & $\mathrm{C}$ & No \\
\hline $34 \mathrm{~S}^{1}$ & 401603074483801 & M & $\mathrm{Su}$ & -- & $8-18$ & 144.90 & 3.53 & 141.37 & $\mathrm{U}$ & No \\
\hline $35 \mathrm{BR}$ & 401600074484602 & M & $\mathrm{St}$ & -- & $31-47$ & 154.75 & $\mathrm{~nm}$ & $\mathrm{~nm}$ & $\mathrm{U}$ & No \\
\hline 35-MW-1 & 401616074484901 & M & $\mathrm{Su}$ & -- & $7-25$ & 168.73 & 11.08 & 157.65 & $\mathrm{U}$ & No \\
\hline 35-MW-2 & 401615074484901 & M & $\mathrm{Su}$ & -- & $6.5-22.5$ & 164.31 & 7.82 & 156.49 & $\mathrm{C}$ & No \\
\hline $35 \mathrm{~S}$ & 401609074483302 & M & $\mathrm{Su}$ & -- & $5-15$ & 153.92 & 8.68 & 145.24 & $\mathrm{C}$ & No \\
\hline 36BR-A & 401608074485102 & $\mathrm{R}$ & $\mathrm{L}$ & H-H' & & 154.10 & 9.34 & 144.76 & $\mathrm{U}$ & No \\
\hline 36BR-B & 401608074485103 & $\mathrm{R}$ & $\mathrm{L}$ & H-H' & $114.14-125$ & 154.10 & 6.50 & 147.60 & $\mathrm{U}$ & No \\
\hline $36 \mathrm{~S}$ & 401613074484401 & M & $\mathrm{Su}$ & -- & $3-13$ & 169.46 & $\mathrm{~nm}$ & $\mathrm{~nm}$ & $\mathrm{U}$ & No \\
\hline 37BR & 401605074483401 & M & St & $\mathrm{C}-\mathrm{C}^{\prime}$ & $60-75$ & 143.39 & 10.52 & 132.87 & $\mathrm{C}$ & No \\
\hline $37 \mathrm{~S}$ & 401605074483701 & M & $\mathrm{Su}$ & -- & $6-16$ & 147.35 & 8.52 & 138.83 & $\mathrm{U}$ & No \\
\hline 38BR & 401609074484601 & M & $\mathrm{L}$ & F-F' & $100-115$ & 150.05 & 6.78 & 143.27 & $\mathrm{U}$ & Yes \\
\hline $38 \mathrm{~S}$ & 401610074483402 & M & $\mathrm{Su}$ & -- & $2-7$ & 149.52 & 4.27 & 145.25 & $\mathrm{U}$ & No \\
\hline 39BR & 401607074484201 & M & $\mathrm{L}$ & E-E' & $68-88$ & 149.05 & 6.66 & 142.39 & $\mathrm{U}$ & No \\
\hline 40BR & 401606074485302 & M & $\mathrm{L}$ & I-I' & $95-120$ & 152.84 & 10.83 & 142.01 & $\mathrm{U}$ & No \\
\hline $40 \mathrm{~S}$ & 401606074485101 & M & $\mathrm{Su}$ & -- & $3-13$ & 148.36 & 6.99 & 141.37 & $\mathrm{C}$ & No \\
\hline $41 \mathrm{BR}$ & 401610074484301 & M & $\mathrm{L}$ & E-E' & $85-110$ & 149.20 & 4.87 & 144.33 & $\mathrm{U}$ & Yes \\
\hline $41 \mathrm{~S}$ & 401606074485001 & M & $\mathrm{Su}$ & -- & $3-13$ & 149.29 & 6.72 & 142.57 & $\mathrm{C}$ & No \\
\hline 42BR & 401607074484202 & M & $\mathrm{L}$ & E-E' & $120-140$ & 148.94 & 6.48 & 142.46 & $\mathrm{U}$ & No \\
\hline $42 \mathrm{~S}$ & 401610074483401 & M & $\mathrm{Su}$ & -- & $3.6-13.6$ & 156.80 & 8.10 & 148.70 & $\mathrm{C}$ & No \\
\hline 43BR & 401613074484101 & M & $\mathrm{L}$ & D-D' & $385-410$ & 168.05 & 23.71 & 144.34 & $\mathrm{U}$ & No \\
\hline 44BR & 401613074484102 & M & $\mathrm{L}$ & D-D' & $305-330$ & 167.41 & 24.49 & 142.92 & $\mathrm{U}$ & No \\
\hline $45 \mathrm{BR}$ & 401610074485101 & P\&T & $\mathrm{L}$ & H-H' & $185-210$ & 157.56 & $\mathrm{~nm}$ & $\mathrm{~nm}$ & $\mathrm{U}$ & No \\
\hline 46BR & 401611074484701 & M & $\mathrm{L}$ & F-F' & $196-221$ & 149.97 & 1.87 & 148.10 & $\mathrm{U}$ & No \\
\hline 47BR & 401609074484502 & M & $\mathrm{L}$ & F-F' & $3-18$ & 149.80 & 5.19 & 144.61 & $\mathrm{U}$ & No \\
\hline 48BR & 401610074483601 & $\mathrm{P} \& \mathrm{~T}$ & $\mathrm{~L}$ & $\mathrm{C}-\mathrm{C}^{\prime}$ & $82-100$ & 159.96 & 30.66 & 129.30 & $\mathrm{U}$ & No \\
\hline 49BR & 401609074483901 & M & $\mathrm{L}$ & D-D' & $42-60$ & 149.02 & 7.25 & 141.77 & $\mathrm{U}$ & No \\
\hline $50 \mathrm{BR}$ & 401612074483001 & M & $\mathrm{L}$ & $A-A^{\prime}$ & $60-80$ & 157.62 & 8.76 & 148.86 & $\mathrm{U}$ & No \\
\hline
\end{tabular}


Table 1. Well information and synoptic groundwater level data, former Naval Air Warfare Center and vicinity, West Trenton, New Jersey, June 18, 2018. - Continued

[NWIS, U.S. Geological Survey National Water Information System; ft, feet; NAVD 88, National Vertical Datum of 1988; CDO, Civil Defense Obs; WDW, West Ditch Well; M, monitoring; P\&T, pump-andtreat; R, research; Su, surficial; L, Lockatong Formation bedrock; St, Stockton Formation bedrock; --, none; nm, not measured; <, water level is below bottom of open interval; U, U.S. Geological Survey; C, U.S. Navy contractor]

\begin{tabular}{|c|c|c|c|c|c|c|c|c|c|c|}
\hline Well name & NWIS site number & $\begin{array}{l}\text { Well } \\
\text { type }\end{array}$ & Hydrogeologic unit & $\begin{array}{l}\text { Line of } \\
\text { section }\end{array}$ & $\begin{array}{l}\text { Open inter- } \\
\text { val depth, } \\
\text { in ft }\end{array}$ & $\begin{array}{c}\text { Land- } \\
\text { surface } \\
\text { altitude, } \\
\text { in ft NAVD88 }\end{array}$ & $\begin{array}{c}\text { Water- } \\
\text { level } \\
\text { depth, in ft }\end{array}$ & $\begin{array}{c}\text { Water-level } \\
\text { altitude, } \\
\text { in ft NAVD } \\
88\end{array}$ & $\begin{array}{c}\text { Measurement } \\
\text { agency }\end{array}$ & $\begin{array}{l}\text { Recorder } \\
\text { installed }\end{array}$ \\
\hline 51BR & 401613074483301 & $\mathrm{M}$ & $\mathrm{L}$ & B-B' & $86-96$ & 156.57 & 15.45 & 141.12 & $\mathrm{C}$ & No \\
\hline $52 \mathrm{BR}$ & 401604074484402 & M & St & F-F' & $155-180$ & 147.23 & 7.10 & 140.13 & $\mathrm{U}$ & No \\
\hline 53BR & 401610074484001 & M & $\mathrm{L}$ & D-D' & $95-120$ & 147.45 & 3.42 & 144.03 & $\mathrm{U}$ & No \\
\hline 54BR & 401608074483401 & M & St & $\mathrm{C}-\mathrm{C}^{\prime}$ & $175-200$ & 152.91 & 13.09 & 139.82 & $\mathrm{U}$ & No \\
\hline $55 \mathrm{BR}$ & 401613074484901 & M & $\mathrm{L}$ & G-G' & $135-160$ & 163.03 & 12.90 & 150.13 & $\mathrm{U}$ & No \\
\hline $56 \mathrm{BR}$ & 401608074484802 & $\mathrm{P} \& \mathrm{~T}$ & $\mathrm{~L}$ & H-H' & $140-165$ & 148.63 & 15.49 & 133.14 & $\mathrm{C}$ & No \\
\hline 57BR & 401606074485303 & M & $\mathrm{L}$ & I-I' & $12-27$ & 151.52 & 6.56 & 144.96 & $\mathrm{C}$ & No \\
\hline $58 \mathrm{BR}^{1}$ & 401607074485602 & M & $\mathrm{L}$ & -- & $85-110$ & 153.88 & 9.88 & 144.00 & $\mathrm{C}$ & Yes \\
\hline $59 \mathrm{BR}^{1}$ & 401606074485601 & M & $\mathrm{L}$ & -- & $56-80$ & 152.63 & 8.49 & 144.14 & $\mathrm{C}$ & No \\
\hline 60BR & 401607074485102 & M & $\mathrm{L}$ & I-I' & $70-85$ & 152.57 & 10.01 & 142.56 & $\mathrm{U}$ & No \\
\hline 61BR & 401609074485001 & M & $\mathrm{L}$ & H-H' & $70-100$ & 156.33 & 11.86 & 144.47 & $\mathrm{U}$ & No \\
\hline $62 \mathrm{BR}$ & 401609074485401 & M & $\mathrm{L}$ & I-I' & $142-167$ & 156.94 & 13.75 & 143.19 & $\mathrm{C}$ & No \\
\hline 63BR & 401605074484602 & M & St & G-G' & $15-40$ & 147.66 & 8.16 & 139.50 & $\mathrm{U}$ & No \\
\hline $64 \mathrm{BR}$ & 401606074485103 & M & $\mathrm{L}$ & I-I' & $15-40$ & 151.62 & 9.19 & 142.43 & $\mathrm{U}$ & No \\
\hline $65 \mathrm{BR}$ & 401605074484401 & M & St & G-G' & $15-40$ & 149.13 & 11.06 & 138.07 & $\mathrm{U}$ & No \\
\hline 66BR & 401608074485401 & M & $\mathrm{L}$ & I-I' & $70-100$ & 156.63 & 12.14 & 144.49 & $\mathrm{C}$ & No \\
\hline $68 \mathrm{BR}$ & 401609074484701 & $\mathrm{R}$ & $\mathrm{L}$ & -- & $14-174.5$ & 149.66 & $\mathrm{~nm}$ & $\mathrm{~nm}$ & $\mathrm{~nm}$ & No \\
\hline 70BR-10 & 401607074485004 & $\mathrm{R}$ & $\mathrm{L}$ & $\mathrm{H}-\mathrm{H}^{\prime}$ & 6-16 & 148.56 & 4.50 & 144.06 & $\mathrm{U}$ & No \\
\hline 70BR-72 & 401607074485005 & $\mathrm{R}$ & $\mathrm{L}$ & H-H' & $68.5-73.5$ & 148.56 & 5.88 & 142.68 & $\mathrm{U}$ & No \\
\hline $71 \mathrm{BR}$ & 401608074485001 & $\mathrm{R}$ & $\mathrm{L}$ & -- & $25-114$ & 148.46 & $\mathrm{~nm}$ & $\mathrm{~nm}$ & $\mathrm{~nm}$ & No \\
\hline 73BR-A & 401607074484903 & $\mathrm{R}$ & $\mathrm{L}$ & H-H' & $25-34.6$ & 148.78 & 5.66 & 143.12 & $\mathrm{U}$ & No \\
\hline 73BR-BC & 401607074484904 & $\mathrm{R}$ & $\mathrm{L}$ & H-H' & $36.9-55.7$ & 148.78 & 4.48 & 144.30 & $\mathrm{U}$ & No \\
\hline 73BR-D1 & 401607074484905 & $\mathrm{R}$ & $\mathrm{L}$ & H-H' & $57.9-83.2$ & 148.78 & 6.16 & 142.62 & $\mathrm{U}$ & No \\
\hline 73BR-D2 & 401607074484906 & $\mathrm{R}$ & $\mathrm{L}$ & $\mathrm{H}-\mathrm{H}^{\prime}$ & $85.5-91.4$ & 148.78 & 6.23 & 142.55 & $\mathrm{U}$ & No \\
\hline 73BR-E & 401607074484907 & $\mathrm{R}$ & $\mathrm{L}$ & H-H' & $93.7-114$ & 148.78 & 4.44 & 144.34 & $\mathrm{U}$ & No \\
\hline 74BR & 401607074484501 & M & $\mathrm{L}$ & F-F' & $52-77$ & 149.62 & 5.64 & 143.98 & $\mathrm{U}$ & No \\
\hline 80BR-A & 401608074484902 & $\mathrm{R}$ & $\mathrm{L}$ & $\mathrm{H}-\mathrm{H}^{\prime}$ & $67.3-78.5$ & 150.33 & 4.42 & 145.91 & $\mathrm{U}$ & No \\
\hline 80BR-B & 401608074484903 & $\mathrm{R}$ & $\mathrm{L}$ & $\mathrm{H}-\mathrm{H}^{\prime}$ & $80.7-86.4$ & 150.33 & 5.37 & 144.96 & $\mathrm{U}$ & No \\
\hline
\end{tabular}


Table 1. Well information and synoptic groundwater level data, former Naval Air Warfare Center and vicinity, West Trenton, New Jersey, June 18, 2018.-Continued

[NWIS, U.S. Geological Survey National Water Information System; ft, feet; NAVD 88, National Vertical Datum of 1988; CDO, Civil Defense Obs; WDW, West Ditch Well; M, monitoring; P\&T, pump-andtreat; R, research; Su, surficial; L, Lockatong Formation bedrock; St, Stockton Formation bedrock; --, none; nm, not measured; <, water level is below bottom of open interval; U, U.S. Geological Survey; C, U.S. Navy contractor]

\begin{tabular}{|c|c|c|c|c|c|c|c|c|c|c|}
\hline Well name & NWIS site number & $\begin{array}{l}\text { Well } \\
\text { type }\end{array}$ & Hydrogeologic unit & $\begin{array}{l}\text { Line of } \\
\text { section }\end{array}$ & $\begin{array}{l}\text { Open inter- } \\
\text { val depth, } \\
\text { in ft }\end{array}$ & $\begin{array}{c}\text { Land- } \\
\text { surface } \\
\text { altitude, } \\
\text { in ft NAVD88 }\end{array}$ & $\begin{array}{c}\text { Water- } \\
\text { level } \\
\text { depth, in ft }\end{array}$ & $\begin{array}{c}\text { Water-level } \\
\text { altitude, } \\
\text { in ft NAVD } \\
88\end{array}$ & $\begin{array}{c}\text { Measurement } \\
\text { agency }\end{array}$ & $\begin{array}{l}\text { Recorder } \\
\text { installed }\end{array}$ \\
\hline 80BR-C & 401608074484904 & $\mathrm{R}$ & $\mathrm{L}$ & H-H' & 88.6-122.9 & 150.33 & 5.30 & 145.03 & $\mathrm{U}$ & No \\
\hline 80BR-D & 401608074484905 & $\mathrm{R}$ & $\mathrm{L}$ & H-H' & & 150.33 & 6.99 & 143.34 & $\mathrm{U}$ & No \\
\hline $83 \mathrm{BR}$ & 401608074484402 & $\mathrm{R}$ & $\mathrm{L}$ & -- & $47-120$ & 150.31 & $\mathrm{~nm}$ & $\mathrm{~nm}$ & $\mathrm{~nm}$ & No \\
\hline 84BR & 401608074484405 & $\mathrm{R}$ & $\mathrm{L}$ & -- & $51-120$ & 150.03 & $\mathrm{~nm}$ & $\mathrm{~nm}$ & $\mathrm{~nm}$ & No \\
\hline $85 \mathrm{BR}$ & 401608074484407 & $\mathrm{R}$ & $\mathrm{L}$ & -- & $46-120$ & 150.39 & $\mathrm{~nm}$ & $\mathrm{~nm}$ & $\mathrm{~nm}$ & No \\
\hline 86BR & 401608074484408 & $\mathrm{R}$ & $\mathrm{L}$ & -- & $39-120$ & 150.39 & $\mathrm{~nm}$ & $\mathrm{~nm}$ & $\mathrm{~nm}$ & No \\
\hline 87BR & 401608074484406 & $\mathrm{R}$ & $\mathrm{L}$ & -- & $39-120$ & 150.29 & $\mathrm{~nm}$ & $\mathrm{~nm}$ & $\mathrm{~nm}$ & No \\
\hline 88BR & 401608074484403 & $\mathrm{R}$ & $\mathrm{L}$ & -- & $44-120$ & 149.86 & $\mathrm{~nm}$ & $\mathrm{~nm}$ & $\mathrm{~nm}$ & No \\
\hline 89BR & 401608074484404 & $\mathrm{R}$ & $\mathrm{L}$ & -- & $51.5-120$ & 149.84 & $\mathrm{~nm}$ & $\mathrm{~nm}$ & $\mathrm{~nm}$ & No \\
\hline 91BR & 401605074485105 & P\&T & $\mathrm{L}$ & H-H' & $7-17$ & 150.00 & 10.38 & 139.62 & $\mathrm{U}$ & No \\
\hline 92BR & 401607074485103 & $\mathrm{R}$ & $\mathrm{L}$ & -- & $45-80$ & 153.94 & $\mathrm{~nm}$ & $\mathrm{~nm}$ & $\mathrm{~nm}$ & No \\
\hline 93BR & 401607074485104 & $\mathrm{R}$ & $\mathrm{L}$ & -- & $40-75$ & 153.86 & $\mathrm{~nm}$ & $\mathrm{~nm}$ & $\mathrm{~nm}$ & No \\
\hline 94BR & 401607074485007 & $\mathrm{R}$ & $\mathrm{L}$ & -- & $35-150$ & 148.84 & $\mathrm{~nm}$ & $\mathrm{~nm}$ & $\mathrm{~nm}$ & No \\
\hline $96 \mathrm{BR}^{2}$ & 401625074484002 & M & $\mathrm{L}$ & -- & $30-55$ & 176.23 & $\mathrm{~nm}$ & $\mathrm{~nm}$ & $\mathrm{~nm}$ & No \\
\hline BRP1 & 401609074484501 & $\mathrm{M}$ & $\mathrm{L}$ & F-F' & $20-60$ & 150.18 & 5.49 & 144.69 & $\mathrm{U}$ & Yes \\
\hline BRP2 & 401605074485001 & $\mathrm{P} \& \mathrm{~T}$ & $\mathrm{~L}$ & H-H' & $25-45$ & 149.32 & 10.20 & 139.12 & $\mathrm{U}$ & No \\
\hline BRP3 & 401607074485101 & $\mathrm{M}$ & $\mathrm{L}$ & $\mathrm{H}-\mathrm{H}^{\prime}$ & $25-45$ & 149.31 & 5.57 & 143.74 & $\mathrm{U}$ & Yes \\
\hline $\mathrm{CDO}^{3}$ & 401552074501801 & M & $\mathrm{L}$ & -- & $33-300$ & 122 & $\mathrm{~nm}$ & $\mathrm{~nm}$ & $\mathrm{~nm}$ & Yes \\
\hline WDW & 401606074485102 & $\mathrm{M}$ & $\mathrm{Su}$ & -- & $0-10.3$ & 147.33 & 5.76 & 141.57 & $\mathrm{U}$ & No \\
\hline
\end{tabular}

${ }^{1}$ Measurement omitted from analysis.

${ }^{2}$ Well constructed November 2018.

${ }^{3}$ Well located off-site. 
Gold Run as if it were a gaining stream, which is also assumed in this report. No data were collected along nor south of Gold Run, so the contours on the southern side of Gold Run are approximate.

Several site monitoring wells were not used for the contour maps and sections. Well $34 \mathrm{~S}$ was not used because the measurement may have been subject to field operator error; the water level of $3.53 \mathrm{ft}$ BLS was at least $4 \mathrm{ft}$ shallower than every other past measurement from 34 S stored in NWIS, and $5 \mathrm{ft}$ shallower than the measurement in nearby well $37 \mathrm{~S}$, which consistently has shallower water levels than well $34 \mathrm{~S}$ (U.S. Geological Survey, 2019). Wells 10BR, 18BR, 19BR, and 21BR also were omitted for contouring because they are located farther north where subsurface information is lacking. Similarly, wells 58BR and 59BR, which are located farther west, also were omitted because of the limited subsurface data. Water-level measurements from each of these wells are included in table 1. Well 96BR was drilled in November 2018 after the water-level synoptic event occurred, and therefore, it has no water-level measurement.

\section{Potentiometric Surface Maps}

Two potentiometric surface maps were developed, one for water levels measured in surficial wells representing groundwater conditions in the surficial saprolite and fill (fig. 4), and one for water levels measured in the bedrock representing a "slice" of the subsurface at an altitude of approximately $100 \mathrm{ft}$ above the North American Vertical Datum of 1988 (NAVD 88) (fig. 5), an altitude that is approximately the center of the groundwater-flow regime in the bedrock aquifers at most of NAWC for which data are available (Lacombe, 2000). This altitude corresponds to depths ranging from about $43 \mathrm{ft} \mathrm{BLS}$ near well 6BR to $76 \mathrm{ft}$ BLS near wells $18 \mathrm{BR}$ and 96BR. The surficial potentiometric surface map indicates a general flow direction to the south-southeast, toward Gold Run, a cone of depression in the bedrock caused by P\&T well 48BR, and a cone of depression in the bedrock caused by the P\&T wells 20BR, 91BR, and BRP-2. Directions of groundwater flow in the bedrock at the 100 -ft altitude generally appear controlled by the P\&T wells. Water levels in the bedrock indicate the presence of five primary cones of depression at this depth; these include the cones of depression surrounding P\&T wells (1) 48BR, (2) 8BR + 29BR, (3) 56BR, (4) $15 \mathrm{BR}+20 \mathrm{BR}$ $+91 \mathrm{BR}+\mathrm{BRP}-2$ in the southwestern corner of the study area, and (5) 22BR. No water level was measured in P\&T well 45BR during this synoptic event because of access issues, so the effect of well 45BR pumping on water levels is unclear from the nearby data and cannot be determined.

Surficial water levels are highest north of the cooling towers, with well 35-MW-1 having the highest water level $(157.65 \mathrm{ft})$ among all surficial wells. Well $37 \mathrm{~S}$ in the southeast corner had the lowest measured water level (138.83 ft), although well 34S likely had a lower water level. Lacombe (2000) indicated an overall flow direction to the southwest during static conditions; this change in direction is likely caused by pumping from the P\&T wells. The hydraulic gradient is steepest in the northwest, flattening out across the site nearer to Gold Run. Water levels also indicate a surficial groundwater divide between building 21 and building 41, with groundwater west of the divide flowing to the West Ditch spring before draining to Gold Run, flowing to the cone of depression caused by 20BR, 91BR, and BRP-2, or flowing directly to Gold Run near building 40. Groundwater east of the divide flows directly to Gold Run south of buildings 21 and 22 or is captured by well 48BR. This groundwater divide also is identifiable at $100 \mathrm{ft}$ above NAVD 88 in fractured bedrock between sections E-E' and F-F' (fig. 5).

The cone of depression around P\&T well 48BR has a steep hydraulic gradient from the VOC and PFAS source area (fig. 4), and flatter gradient to the west. However, the full extent of these gradients cannot be definitively determined due to a lack of information about the subsurface beneath building 22. Well 48BR may capture some of the southeast-flowing groundwater from the northwest as well as groundwater from the south that would otherwise be at lower hydraulic head; note that this interpretation can be substantiated only using a numerical flow model with particle tracking. High water levels in wells 29S, 30S, 35S, and 42S indicate some of the groundwater at the VOC and PFAS source area may not be intercepted by well 48BR, but instead may flow south toward Gold Run and possibly east, away from the site. However, lack of water-level data to the east limits the assessment of groundwater flow east of the source area.

In the fractured bedrock, the cone of depression around P\&T well 48BR at $100 \mathrm{ft}$ above NAVD 88 also causes a steep hydraulic gradient from the northeast that may indicate the capture of groundwater flow from the VOC and PFAS source area (fig. 5). Similar to the saprolite, the number of wells open to bedrock in the vicinity of well 48BR is insufficient to accurately assess the size and shape of the cone of depression at well 48BR. The presence of the fault, however, reduces the extent of the cone of depression at this depth (fig. 5).

Groundwater divides at $100 \mathrm{ft}$ above NAVD 88 are present around building 41 between cross sections F-F' and G-G' where groundwater to the north flows toward wells $8 \mathrm{BR}$ and $29 \mathrm{BR}$, groundwater to the west flows east toward a small cone of depression caused by pumping from well 56BR, and groundwater to the south flows toward the cone of depression created by wells $15 \mathrm{BR}, 20 \mathrm{BR}, 91 \mathrm{BR}$, and BRP-2 in the southwestern corner of the site. This suite of wells captures some of the VOC-contaminated water from the VOC source area at this altitude (Lacombe, 2000) and may also capture some component of groundwater flow from the Gold Run spring area, where the VOC-contaminated water would discharge during static conditions (Lacombe, 2000). Therefore, the P\&T system appears to be preventing at least some of the plume from the VOC source area at the NAWC from discharging to the spring, but the extent cannot be determined by using conceptual, generalized flow directions alone. 


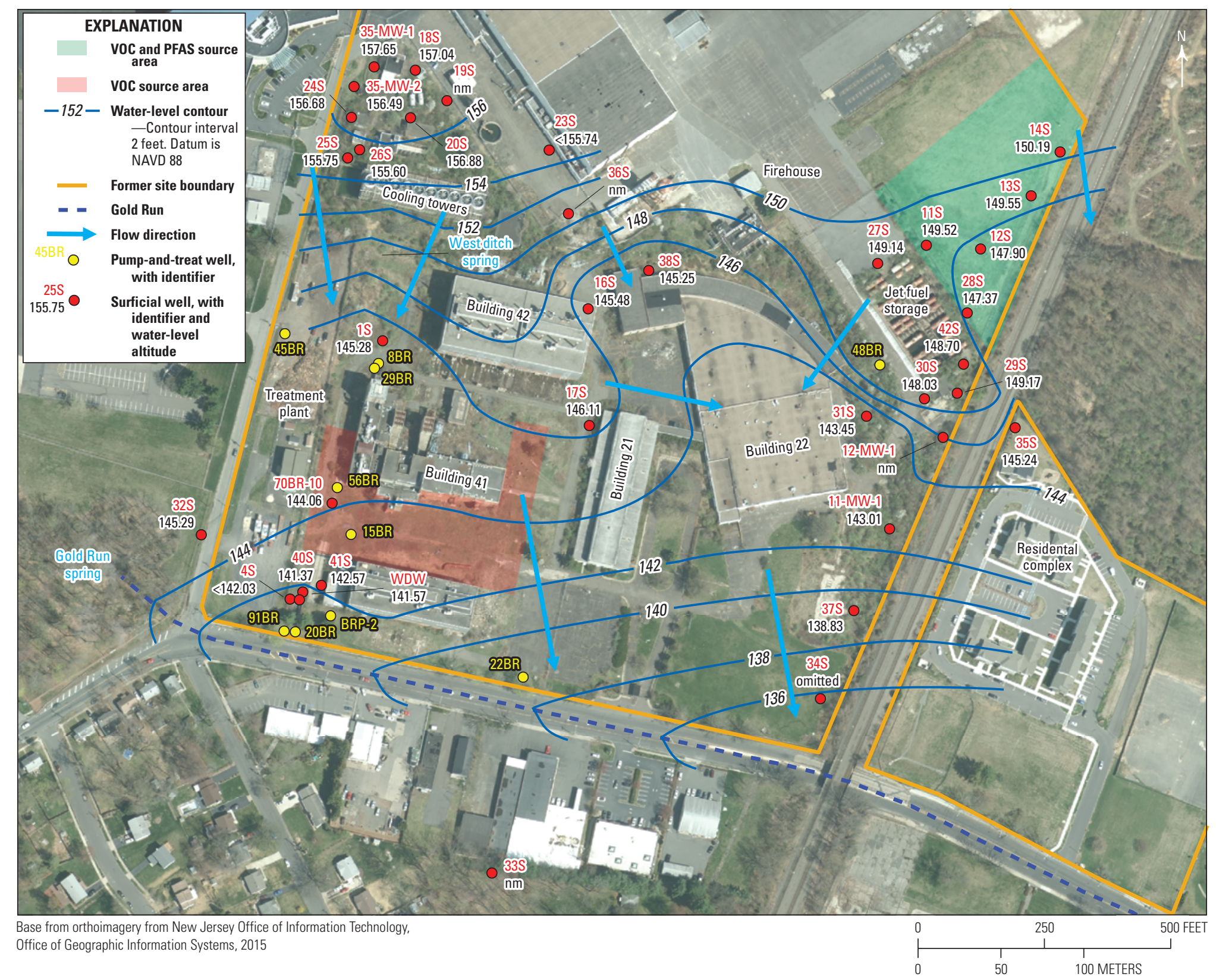

Figure 4. Groundwater levels, water-level potentiometric-surface contours, and groundwater-flow directions in the saprolite and fill, June 2018. Groundwater levels and contours are in feet. [VOC, volatile organic compounds, PFAS, per- and polyfluoroalkyl substances; NAVD 88, North American Vertical Datum of 1988] 


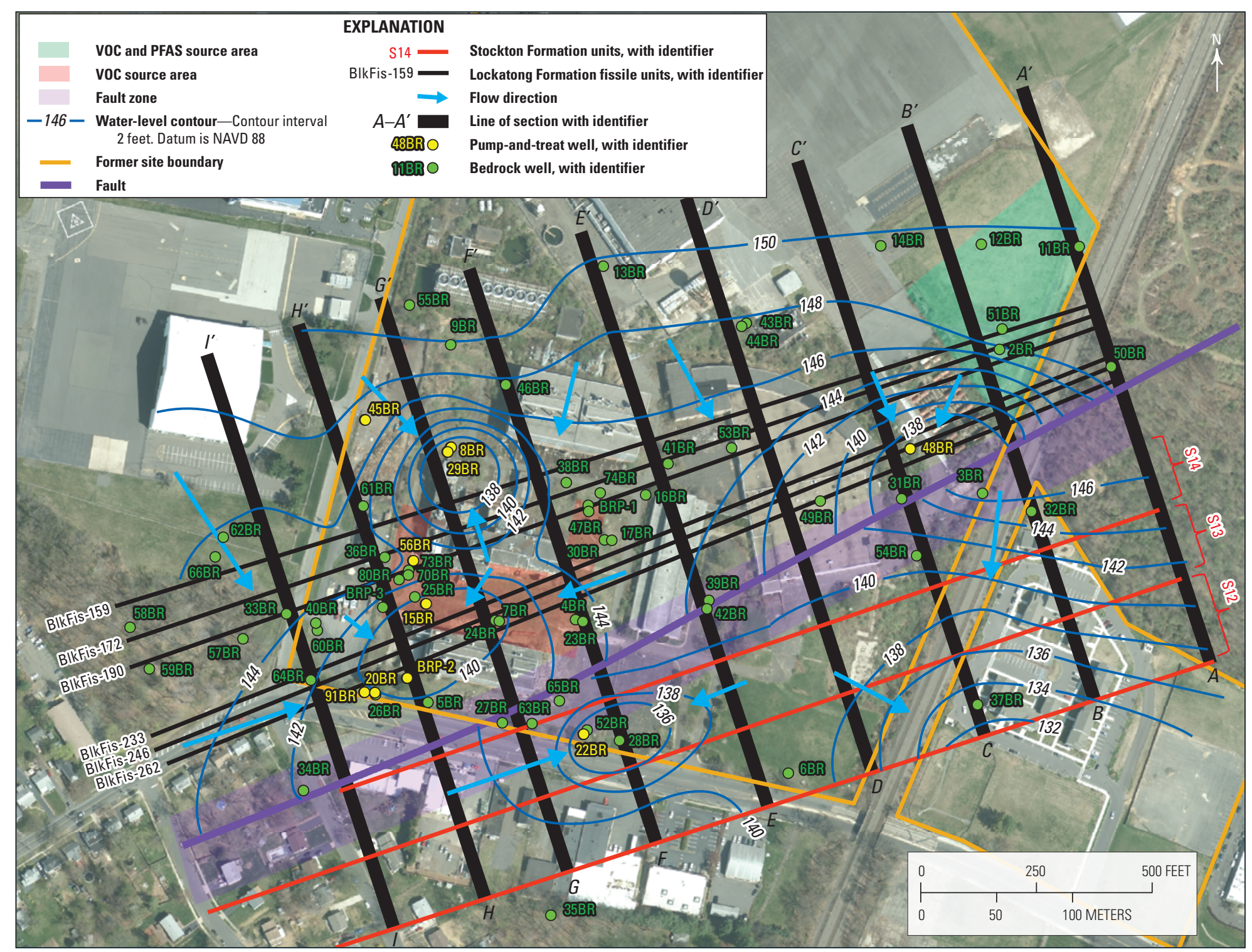

Base from orthoimagery from New Jersey Office of Information Technology,

Office of Geographic Information Systems, 2015

Figure 5. Generalized water-level potentiometric-surface contours and generalized groundwater-flow directions in fractured bedrock at an altitude of approximately 100 feet above the North American Vertical Datum of 1988, June 2018. Potentiometric contours are in feet. [VOC, volatile organic compounds, PFAS, per- and polyfluoroalkyl substances; NAVD 88, North American Vertical Datum of 1988] 
Well 22BR creates a cone of depression in the Stockton Formation, pulling groundwater from a large area. A groundwater divide occurs near well 6BR between sections D-D' and E-E', with groundwater to the west flowing to well 22BR and groundwater to the east flowing southward off site.

\section{Groundwater Levels and Vertical Flow Directions in Dip-Aligned Sections}

Nine cross sections were developed to show subsurface potentiometric contours and assess the vertical component of groundwater flow (figs. 6 through 14). The geometry of these sections is the same as the geometry described by Lacombe and Burton (2010), with the following exceptions: land-surface topography was determined from light detection and ranging (lidar) data; only the water-bearing black fissile (BlkFis) units are shown in the Lockatong Formation; only the bottom of the saprolite and fill, and not the bottom of the weathered zone, is included; and shallow wells in the saprolite are not included. The sections are oriented perpendicular to the strike of the Lockatong Formation beds, and most wells are projected onto the section along strike. In viewing these cross sections, the reader should keep in mind that the overall preferential flow direction in dipping Newark Basin strata is along strike (Michalski and Britton, 1997), perpendicular to the plane of the dip sections, that is, into or out of the page. The major component of flow in the strike direction is, by definition, not illustrated in these dip-aligned sections.

Many cross sections that contain P\&T wells and (or) several water-level observations indicate the vertical component of groundwater flow in the subsurface. Similar results also were identified by Lacombe (2000) and Lacombe (2018). In section B-B' (fig. 7), groundwater flows downward from well 2BR (water level $148.90 \mathrm{ft}$ ) to well 51BR (141.12 ft) through the water-bearing black fissile unit BlkFis-172, which intersects both wells. In section C-C' (fig. 8), groundwater flows toward well 48BR, with upward flow to well 48BR in the suite of black fissile units BlkFis-233, BlkFis-246, and BlkFis-262.

In section F-F' (fig. 11), groundwater flows downward from wells 47BR and BRP-1 (144.61 ft and $144.69 \mathrm{ft}$, respectively) to well 74BR (143.98 ft) in the suite of black fissile units BlkFis-159, BlkFis-172, and BlkFis-190. With the exception of well 46BR (148.1 ft), which is open to extremely low transmissivity units (Fiore, 2014) and likely not hydraulically connected to the shallow system, water levels in all the other Lockatong Formation bedrock wells in section F-F' indicate vertical flow in that section. The apparent vertical flow toward 30BR, which is not a P\&T well, is likely an artifact of the limitations of using the traditional contouring method in a fractured rock setting. Tiedeman and others (2010) noted a minor response in well 30BR to pumping in P\&T well 56BR. The lower water level in 30BR is likely caused by pumping in 56BR. Wells 24BR and 38BR also appear to have flow toward 30BR caused by P\&T well 56BR, but 24BR does not respond to 56BR (Tiedeman and others, 2010) and 38BR is predominantly affected by pumping in 15BR (Lacombe, 2000), so the 142-ft potentiometric contour around well 30BR is unlikely to correspond to groundwater flow toward 30BR.

In section G-G' (fig. 12), P\&T wells 8BR and 29BR intercept groundwater from black fissile units BlkFis-159, BlkFis-172, and BlkFis-190. The groundwater divide between the cone of depression surrounding wells 8BR and 29BR and the southwest cone of depression near building 41 is also inferred to occur at this depth on section G-G'. Wells 8BR and 29BR were not in use during synoptic events described in Lacombe (2000) and Lacombe (2018), during which time the effect of the group of P\&T wells $15 \mathrm{BR}+20 \mathrm{BR}+91 \mathrm{BR}$ + BRP-2 on water levels in wells 7BR and 24BR were more apparent. Furthermore, the potentiometric surface contour around that divide in 2018 was $142 \mathrm{ft}$, which would occur along the groundwater flowpath from 38BR $(143.27 \mathrm{ft}$; section F-F') to 15BR (138.74 ft; section H-H'), bypassing the zone of influence from wells 8BR+29BR. This also provides an example of how groundwater, and hence groundwater contamination, flows at NAWC along strike, which is not apparent on these dip-aligned sections.

Section H-H' (fig. 13) indicates a subsurface groundwater divide caused by pumping from P\&T wells in black fissile units BlkFis-233, BlkFis-246, and BlkFis-262 at an approximate altitude of $30 \mathrm{ft}$ above NAVD 88 near wells 36BR-B, 80BR-C, and 80BR-D. Groundwater above this subsurface divide flows upward to the cone of depression caused by the pumping from the suite of $\mathrm{P} \& \mathrm{~T}$ wells in the southwestern part of the site. Groundwater below this divide flows downward to P\&T well 56BR and likely well 45BR. Water levels in the suite of black fissile units BlkFis-159, BlkFis-172, and BlkFis-190 in section H-H' indicate negligible vertical effects from the southwest cone of depression, because water levels in the wells open to these units (wells 73BR-A, 73BR-BC, 61BR) are elevated; however, these water levels do not obviate the possibility of a hydraulic connection at this location, as indicated by Tiedeman and others $(2010,2018)$. However, each of the four P\&T wells that cause the southwest cone of depression (wells 15BR, 20BR, 91BR, and BRP-2) are located along section $\mathrm{H}-\mathrm{H}$ ' and cause upwards groundwater flow in black fissile units Blk-Fis233, BlkFis-246, and BlkFis-262.

Section H-H' also provides an example of the limitations associated with using the traditional method of contouring water levels in fractured rock. Many wells with multiple depth intervals isolated with packers are located within less than $100 \mathrm{ft}$ of each other, which allows for a high number of water-level measurements to be collected in the same location at different depth intervals. The 144-ft potentiometric contour follows a tortuous path around wells 25BR, 36BR-A, 70BR-72, multiple intervals of 73BR, and multiple intervals of 80BR. The shape of this contour is an artifact of the traditional contouring method and therefore, groundwater-flow directions should not be interpreted beyond broader generalizations. Such a high density of water-level data is not available at any other location at NAWC, and the wells with multiple isolated 
depth intervals did not exist when Lacombe $(2000,2018)$ was interpreting groundwater-flow directions, so this effect is only apparent in section H-H' among this group of wells.

Water levels in section I-I' (fig. 14) indicate no clear vertical component of groundwater flow. Lacombe $(2000,2018)$ interpreted general upward flow toward Gold Run, which also is assumed here. Upward flow in section I-I' likely occurs predominantly in black fissile unit BlkFis-262.

Section-view potentiometric contours in the Stockton Formation indicate similar flow direction results as those in map view. Sections A-A' (fig. 6), B-B' (fig. 7), and C-C' (fig. 8) indicate that groundwater flows away from the fault and away from NAWC. This corresponds to the flow east of the aforementioned groundwater divide between sections D-D' (fig. 9) and E-E' (fig. 10). Sections F-F' (fig. 11) and G-G' (fig. 12) indicate that groundwater flows toward P\&T well 22BR, which corresponds to flow west of the divide. As noted above, the predominant component of flow in the strike direction is, by definition, not shown on these dip-aligned sections.

\section{Summary}

The U.S. Geological Survey, in cooperation with the U.S. Navy, conducted a study of groundwater-level conditions at the decommissioned Naval Air Warfare Center (NAWC) in West Trenton, New Jersey. The results of investigations discussed in this report include continuous groundwater-level data for 6 wells at the NAWC and vicinity from January 1, 2018, through December 31, 2018, and discrete water levels measured in 110 wells on June 18, 2018.

Continuously monitored water levels responded to precipitation, pump-and-treat (P\&T) well withdrawals, and seasonal changes. The largest 1-day increase in water levels occurred from a 3-day storm on November 24-26 that produced 3.5 inches of precipitation and resulted in 2018 annual high water levels in NAWC wells. Annual high water levels occurring in November is seasonally atypical; annual highs usually occur in spring following low evapotranspiration during winter, and annual lows usually occur in fall following high evapotranspiration during summer. A record high November precipitation total for 2018 occurred during a record high annual precipitation total, and P\&T wells 20BR, 91BR, and BRP-2 were shut down during November, all of which combined to cause this uncharacteristic condition.

The discrete water-level data were used to infer generalized flow directions in the fractured bedrock aquifer and overlying saprolite and fill. Groundwater-flow directions in the bedrock are primarily toward P\&T wells within the black fissile strata in the Lockatong Formation, toward well 22BR west of a groundwater divide in the Stockton Formation near well 6BR, and south-southeast exiting the site east of the groundwater divide in the Stockton Formation near well 6BR. Water levels also indicate that the P\&T wells capture much of the groundwater flowing in the bedrock within the boundaries of the NAWC, especially in the volatile organic compound (VOC) source area, thus minimizing off-site migration of contaminated groundwater. The fault separating the Lockatong and Stockton Formations is a low-permeability barrier to groundwater flow and causes a difference in hydraulic heads between the two sides of the fault. Groundwater flow in the saprolite and fill is primarily toward Gold Run, although some surficial groundwater is intercepted by P\&T well 48BR. Water levels in surficial wells in the VOC and per- and polyfluoroalkyl substances source area in the northeastern corner of the NAWC indicate that groundwater in the saprolite at this location has the potential to flow off site toward the east. 


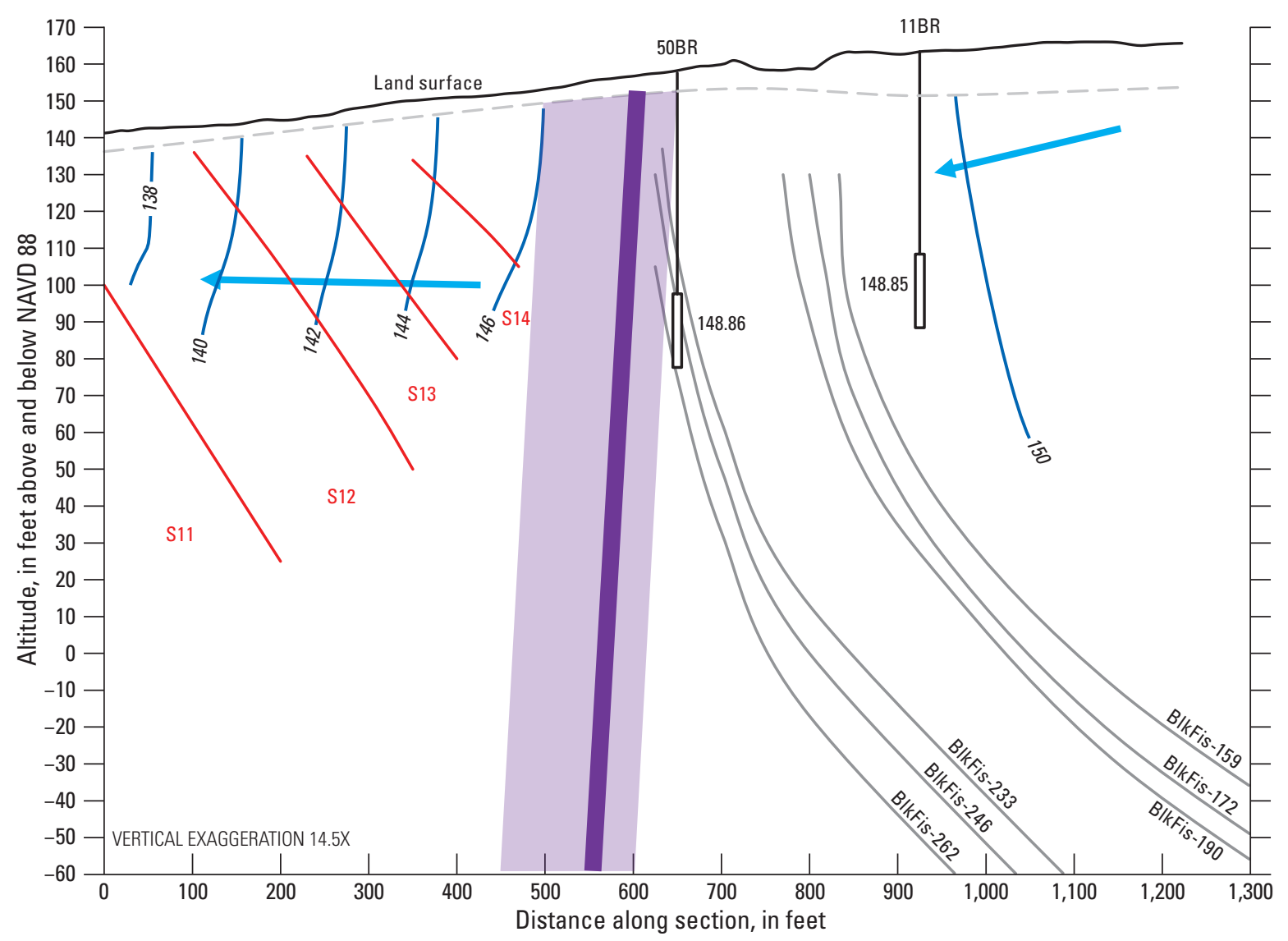

\section{EXPLANATION}

Fault zone

Fault

$\longleftarrow$ Flow direction

_ Lockatong Formation fissile unit

— Stockton Formation unit top

- Water-level contour-Contour interval 2 feet. Datum is NAVD 88

-- Bottom of saprolite

$148.86 \prod_{\begin{array}{c}\text { Well (* } \\ \text { and water level }\end{array}}^{50 B R \text { wing with identifier }}$

Figure 6. Groundwater levels in wells, generalized water-level potentiometric-surface contours, and generalized flow-direction components in the dip direction, Section A-A'. Water levels and potentiometric contours are in feet. [NAVD 88; North American Vertical Datum of 1988] 


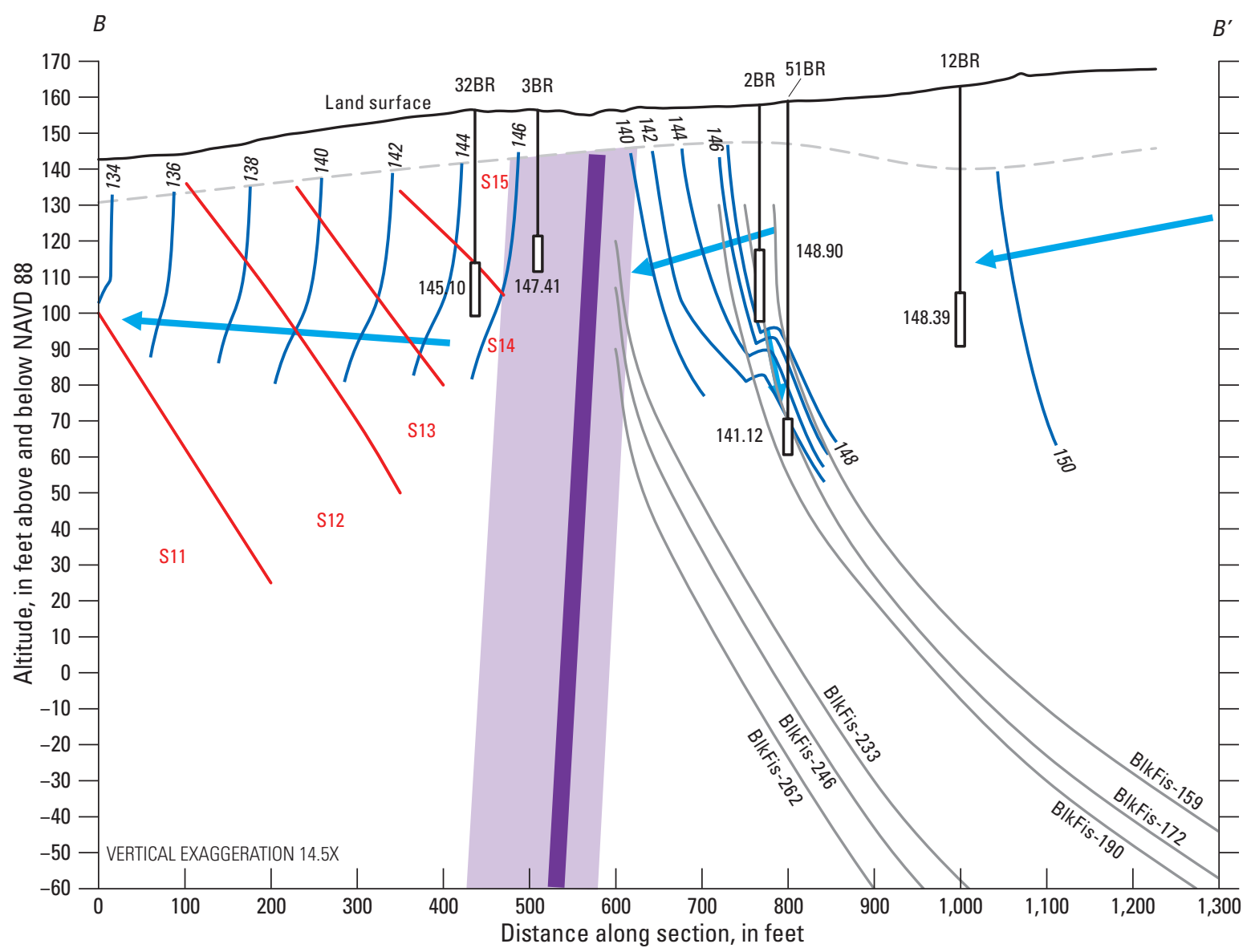

\section{EXPLANATION}

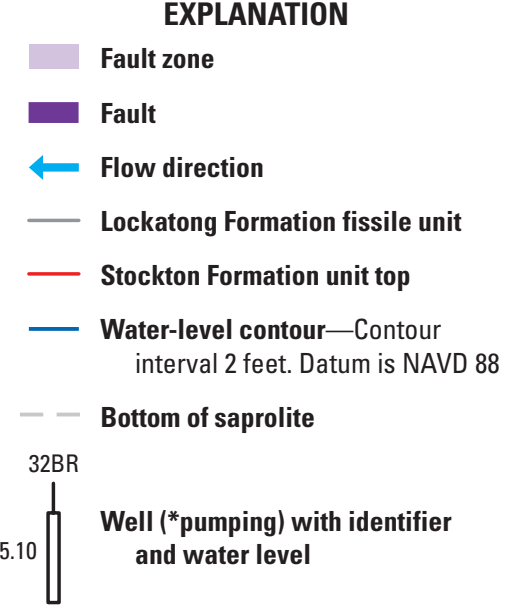

Figure 7. Groundwater levels in wells, generalized water-level potentiometric-surface contours, and generalized flow-direction components in the dip direction, Section B-B'. Water levels and potentiometric contours are in feet. [NAVD 88; North American Vertical Datum of 1988] 


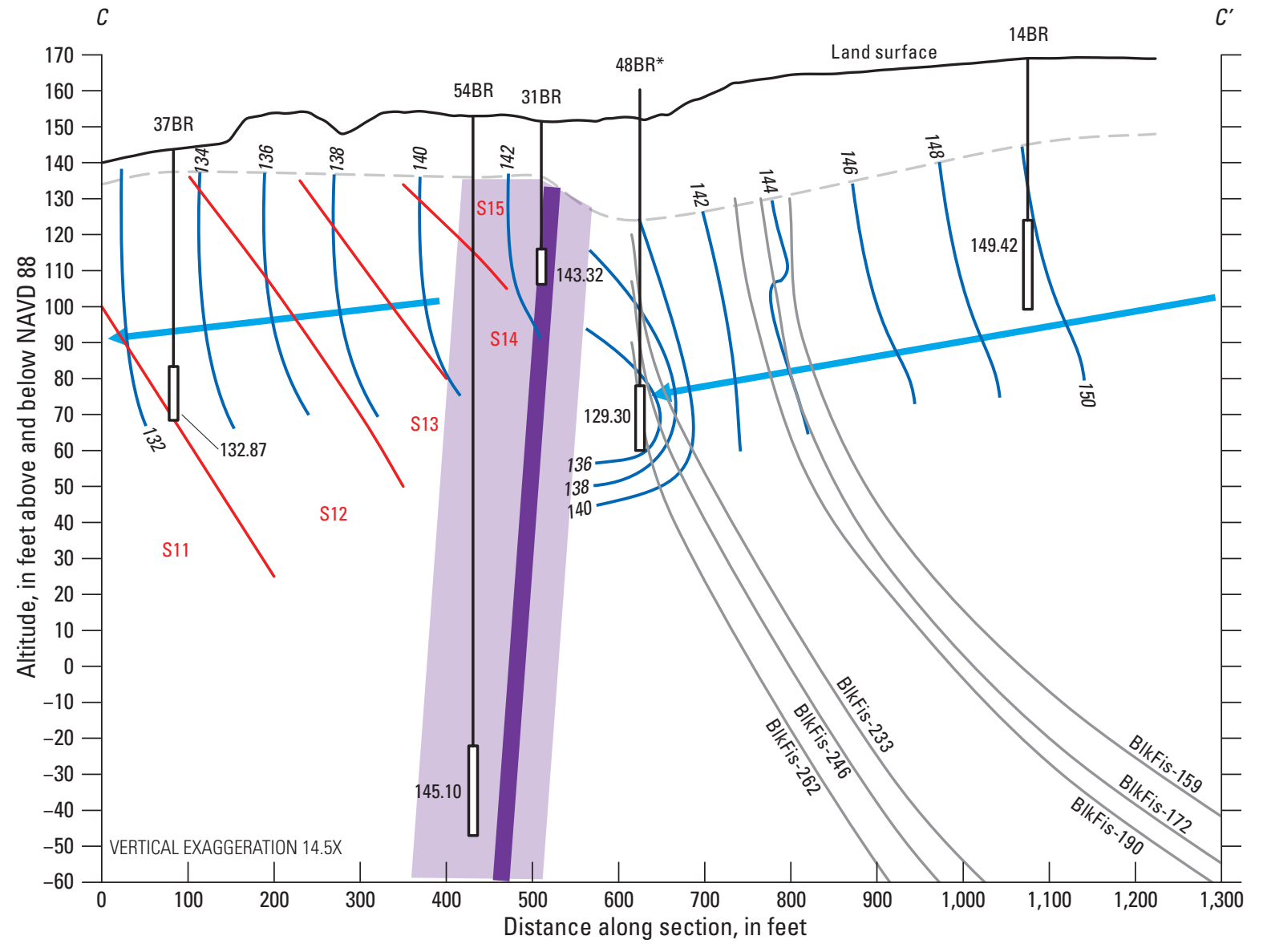

EXPLANATION

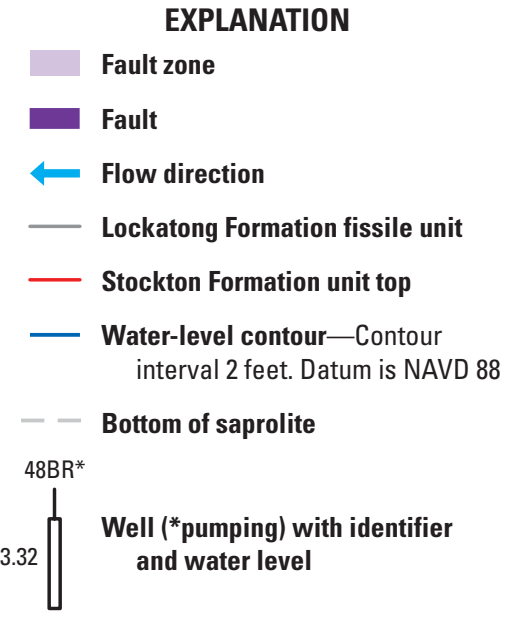

Figure 8. Groundwater levels in wells, generalized water-level potentiometric-surface contours, and generalized flow-direction components in the dip direction, Section C-C'. Water levels and potentiometric contours are in feet. [NAVD 88; North American Vertical Datum of 1988] 


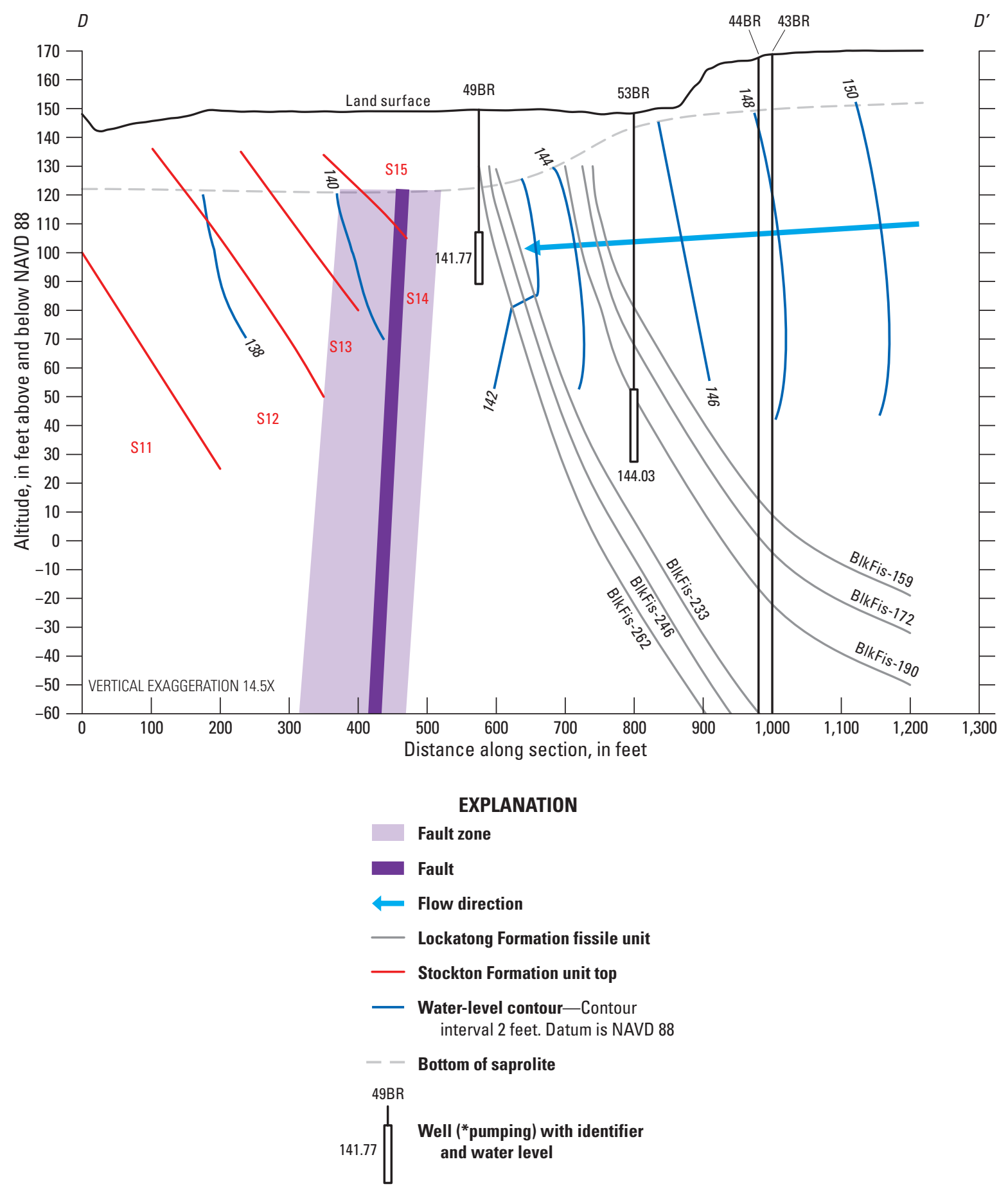

Figure 9. Groundwater levels in wells, generalized water-level potentiometric-surface contours, and generalized flow-direction components in the dip direction, Section D-D'. Water levels and potentiometric contours are in feet. [NAVD 88; North American Vertical Datum of 1988] 


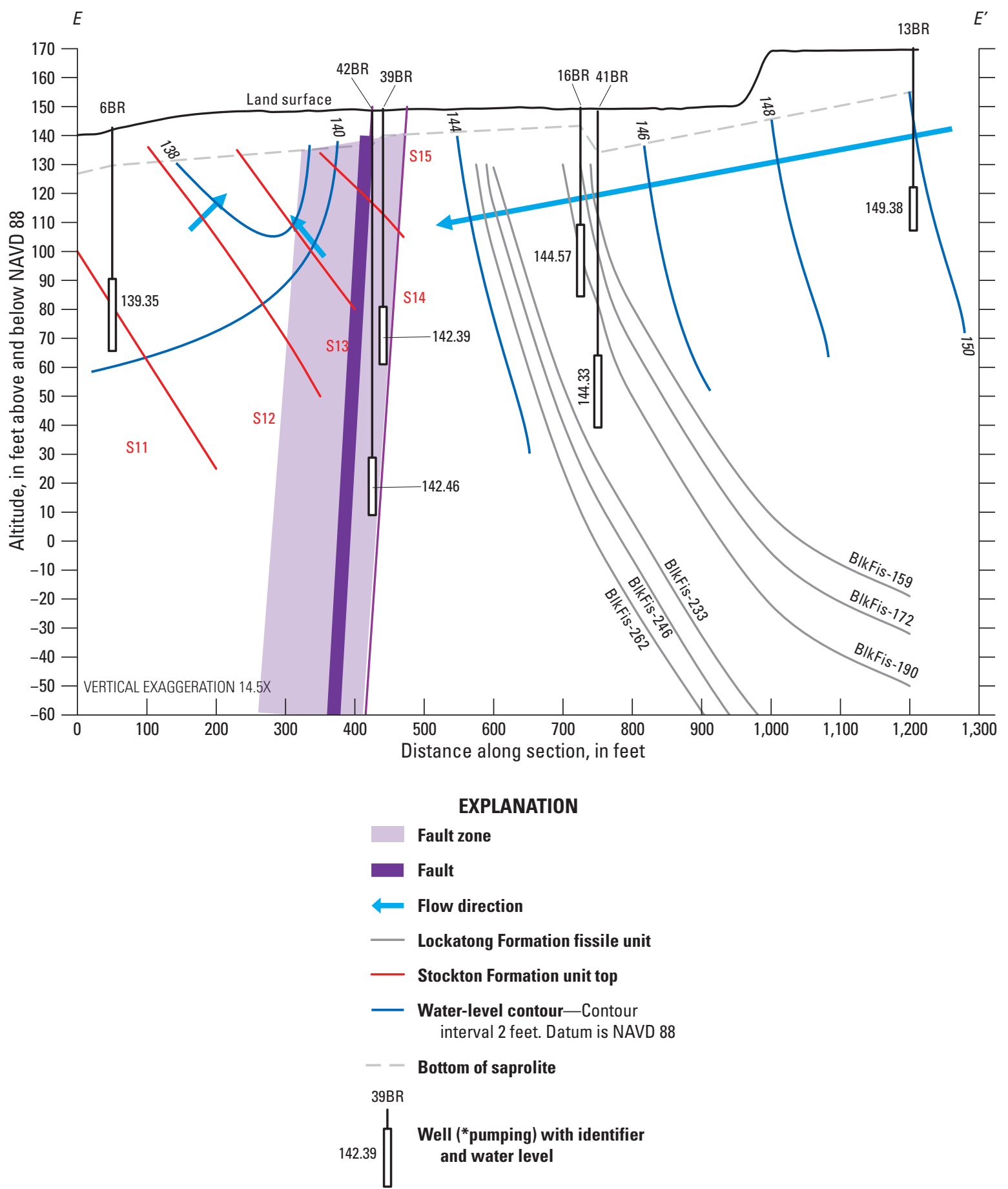

Figure 10. Groundwater levels in wells, generalized water-level potentiometric-surface contours, and generalized flow-direction components in the dip direction, Section E-E'. Water levels and potentiometric contours are in feet. [NAVD 88; North American Vertical Datum of 1988] 
$F$

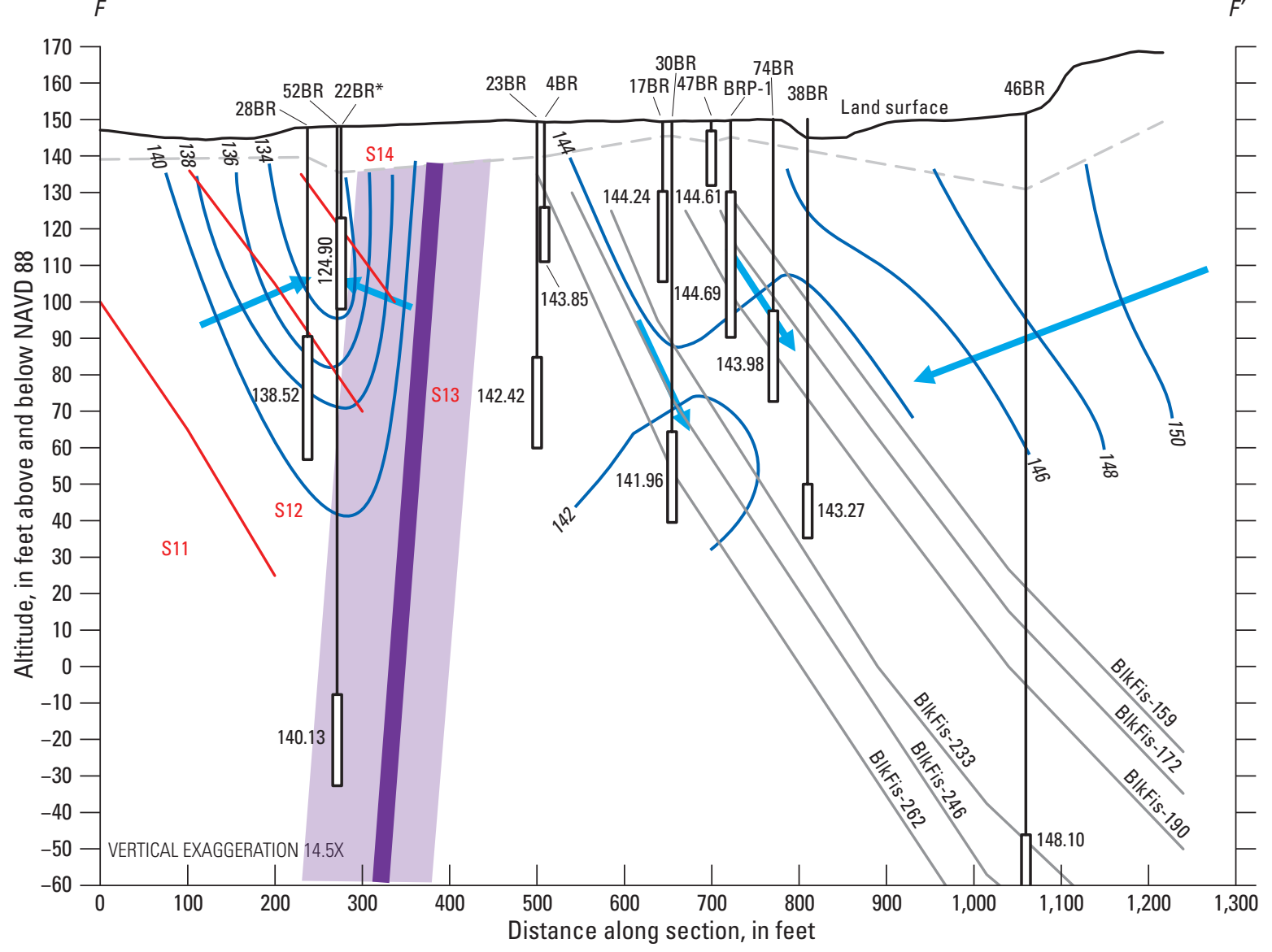

EXPLANATION

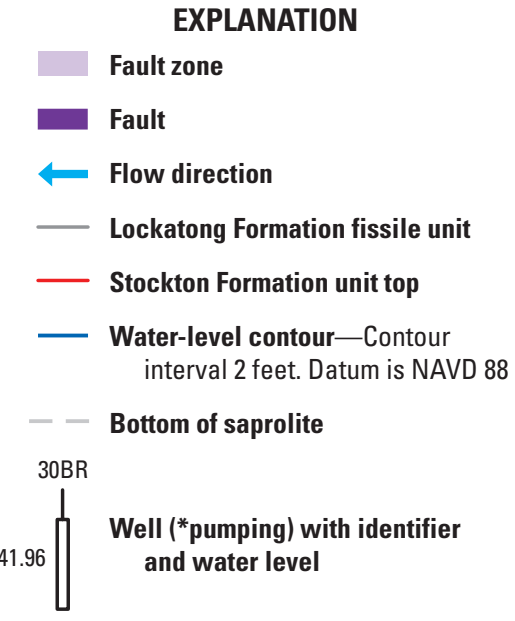

Figure 11. Groundwater levels in wells, generalized water-level potentiometric-surface contours, and generalized flow-direction components in the dip direction, Section F-F'. Water levels and potentiometric contours are in feet. [NAVD 88; North American Vertical Datum of 1988] 


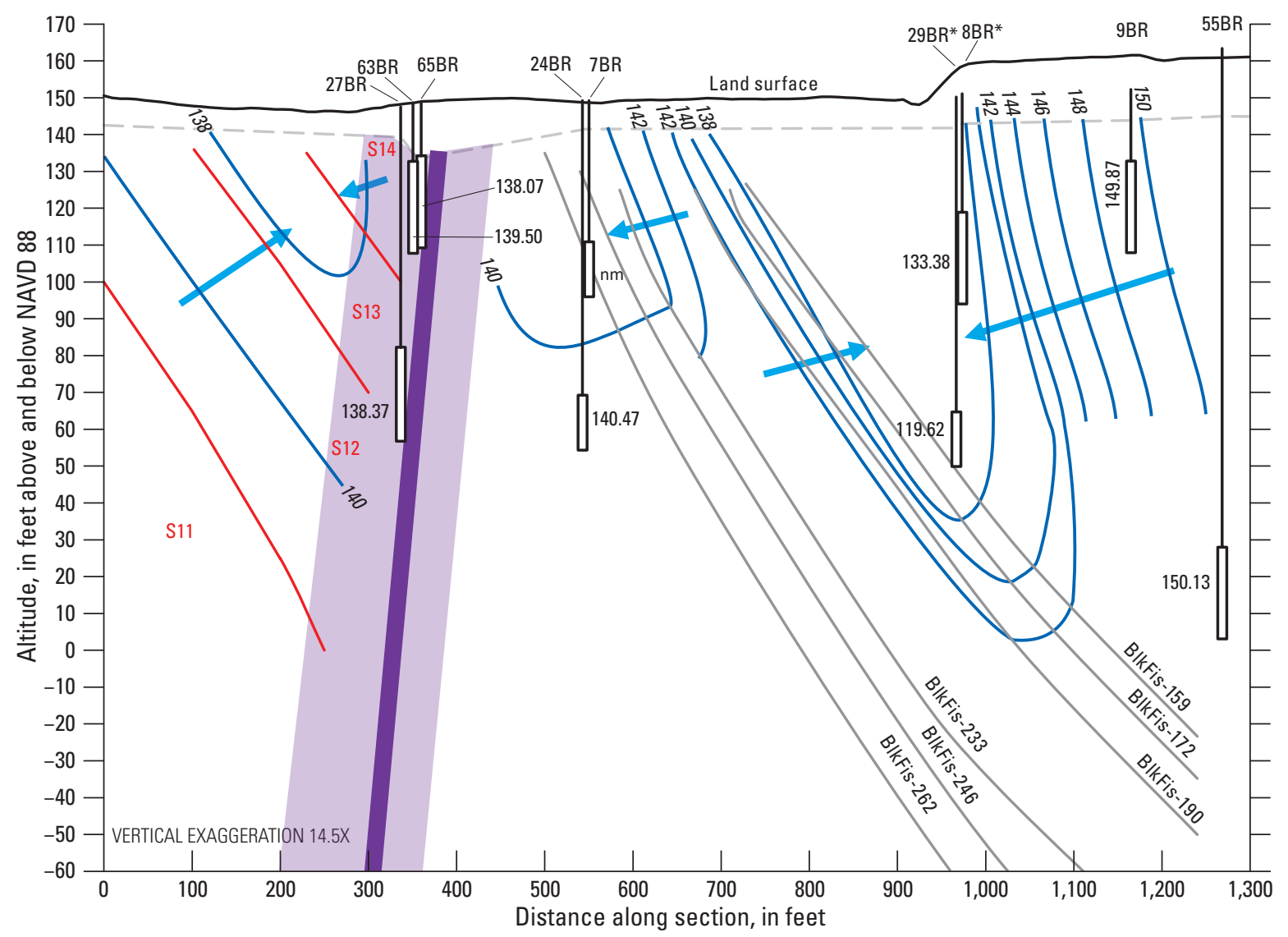

EXPLANATION

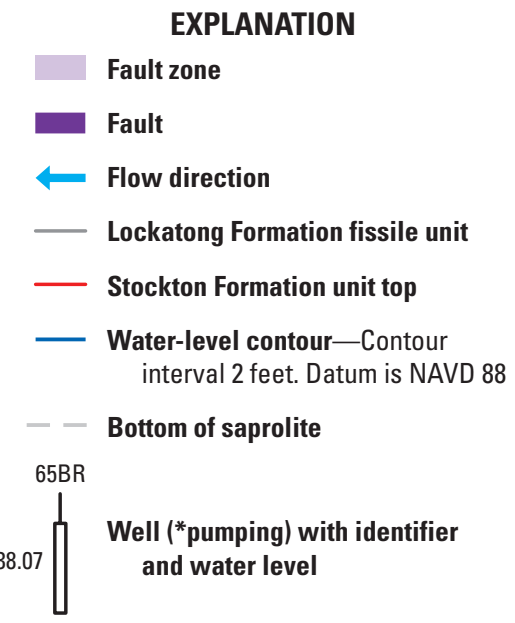

Figure 12. Groundwater levels in wells, generalized water-level potentiometric-surface contours, and generalized flow-direction components in the dip direction, Section G-G'. Water levels and potentiometric contours are in feet. [NAVD 88; North American Vertical Datum of 1988] 


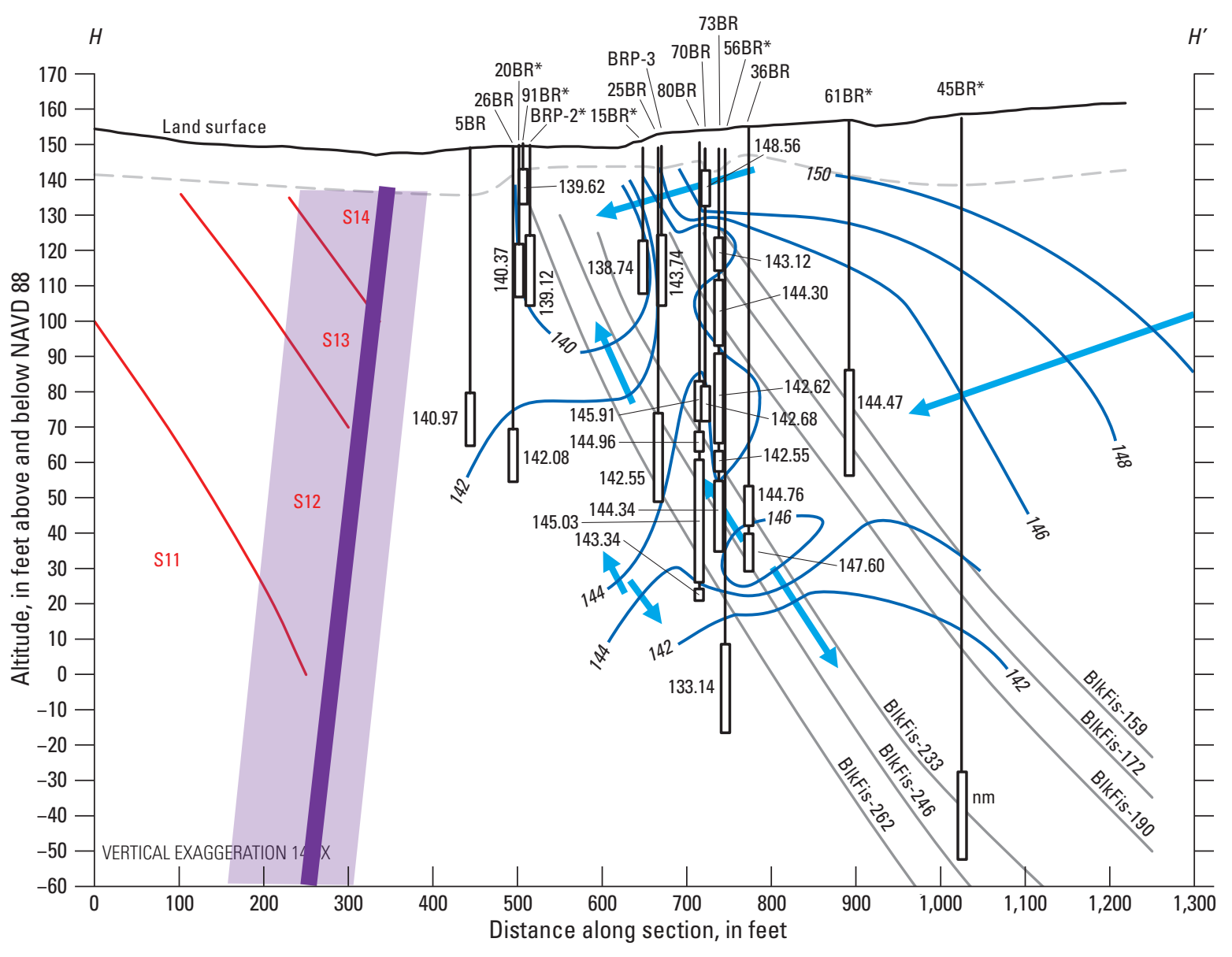

EXPLANATION

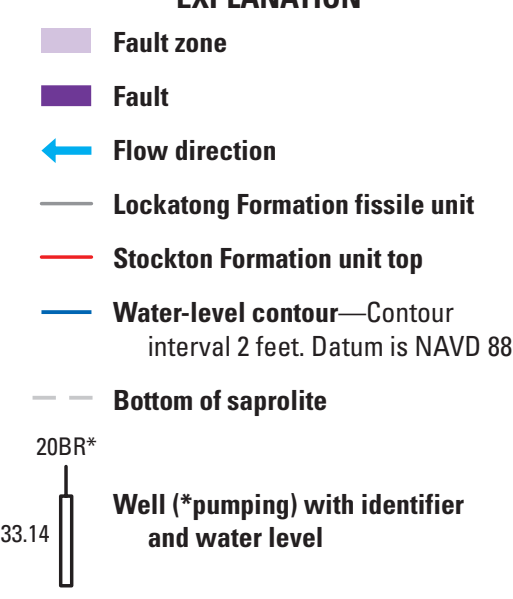

Figure 13. Groundwater levels in wells, generalized water-level potentiometric-surface contours, and generalized flow-direction components in the dip direction, Section $\mathrm{H}-\mathrm{H}^{\prime}$. Water levels and potentiometric contours are in feet. [NAVD 88; North American Vertical Datum of 1988] 


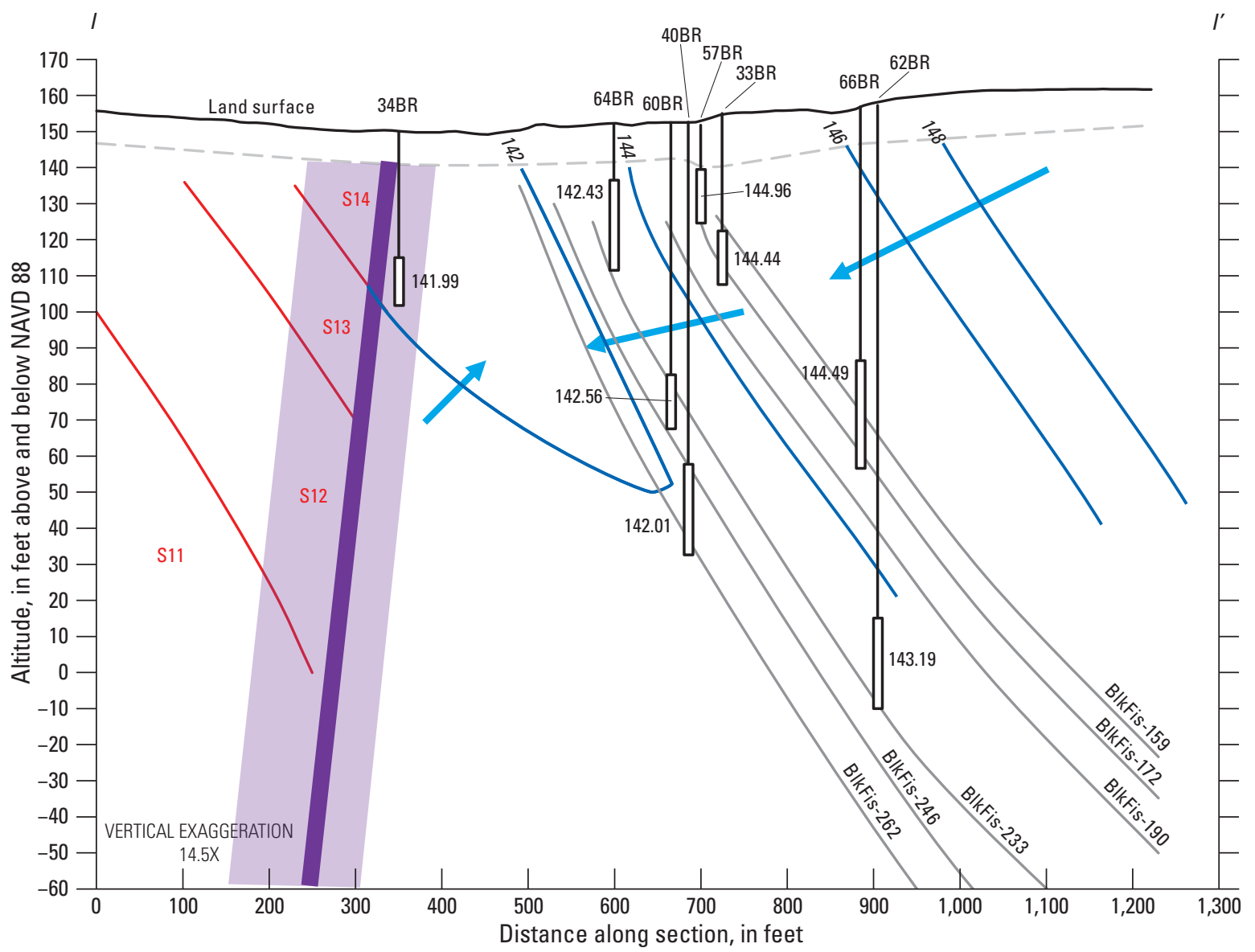

\section{EXPLANATION}

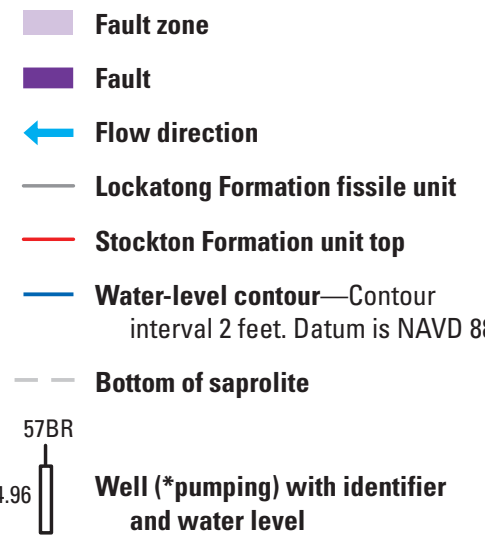

Figure 14. Groundwater levels in wells, generalized water-level potentiometric-surface contours, and generalized flow-direction components in the dip direction, Section I-I. Water levels and potentiometric contours are in feet. [NAVD 88; North American Vertical Datum of 1988] 


\section{References Cited}

EA Engineering, Science, and Technology, Inc., 2000, Final decision document for ground water at the Naval Air Warfare Center, Aircraft Division, Trenton, N.J: Berkeley Heights, N.J., EA Engineering, Science, and Technology, Inc., [n.p.].

Fiore, A.R., 2014, Transmissivity and storage coefficient estimates from slug tests, Naval Air Warfare Center, West Trenton, New Jersey: U.S. Geological Survey Open-File Report 2014-1020, 12 p., accessed April 24, 2019, at https://doi.org/10.3133/ofr20141020.

Fiore, A.R., 2020, Reported groundwater levels and groundwater pump-and-treat withdrawals, former Naval Air Warfare Center, West Trenton, New Jersey, 2018: U.S. Geological Survey data release, https://doi.org/10.5066/ P98N1GWV.

Fiore, A.R., 2019, Summary of borehole information at the former Naval Air Warfare Center, West Trenton, New Jersey: U.S. Geological Survey data release, accessed November 12, 2019, at https://doi.org/10.5066/P9KL4IL2.

International Technology Corporation (IT Corp), 1994, Remedial Investigation Report, Installation Restoration Program, Naval Air Warfare Center, Trenton, New Jersey 6 vols.: Edison, N.J., International Technology Corporation.

Koman Government Solutions, LLC, 2018, January 2018 through December 2018 Groundwater Treatment Facility Report, Former Naval Air Warfare Center, Trenton NJ: Exton, Pa., Koman Government Solutions, LLC, [n.p.].

Lacombe, P.J., 2000, Hydrogeologic framework, water levels, and trichloroethylene contamination, Naval Air Warfare Center, West Trenton, New Jersey, 1993-97: U.S. Geological Survey Water-Resources Investigations Report 98-4167, 139 p., accessed April 26, 2019, at https://doi.org/ 10.3133/wri984167.

Lacombe, P.J., 2018, Ground-water levels and potentiometric surfaces, Naval Air Warfare Center, West Trenton, New Jersey, 2000 (ver. 1.1, August 2018): U.S. Geological Survey Water-Resources Investigations Report 2001-4197, 38 p., accessed April 26, 2019, at https://doi.org/10.3133/ wri014197.

Lacombe, P.J., and Burton, W.C., 2010, Hydrogeologic framework of fractured sedimentary rock, Newark Basin, New Jersey: Ground Water Monitoring and Remediation, v. 30, no. 2, p. 35-45, accessed April 22, 2018, at https://doi.org/ 10.1111/j.1745-6592.2010.01275.x.
Lewis-Brown, J.C., Carleton, G.B., and Imbrigiotta, T.E., 2006, Hydraulic and solute-transport properties and simulated advective transport of contaminated ground water in a fractured rock aquifer at the Naval Air Warfare Center, West Trenton, New Jersey, 2003: U.S. Geological Survey Scientific Investigations Report 2005-5049, 32 p., accessed April 26, 2019, at https://doi.org/10.3133/sir20055049.

Lewis-Brown, J.C., and Rice, D.E., 2002, Simulated groundwater flow, Naval Air Warfare Center, West Trenton, New Jersey: U.S. Geological Survey Water-Resources Investigations Report 2002-4019, 44 p., accessed April 26, 2019, at https://doi.org/10.3133/wri024019.

Michalski, A., and Britton, R., 1997, The role of bedding fractures in the hydrogeology of sedimentary bedrock-Evidence from the Newark Basin, New Jersey: Groundwater, v. 35, no. 2, p. 318-327, accessed April 26, 2019, at https://doi.org/10.1111/j.17456584.1997.tb00089.x.

Office of the New Jersey State Climatologist, 2018, Historical Monthly Station Data: Office of the New Jersey State Climatologist web page, accessed December 18, 2018, at http://climate.rutgers.edu/stateclim_v1/monthlydata/ index.php?stn $=288883 \&$ elem $=$ pcpn

TetraTech, 2018, Final Evaluation of Potential Sources of Per and Polyfluoroalkyl Substances, Former Naval Air Warfare Center Trenton, Trenton, New Jersey: Norfolk, Va., TetraTech, [n.p.].

Tiedeman, C.R., Lacombe, P.J., and Goode, D.J., 2010, Multiple well-shutdown tests and site-scale flow simulation in fractured rocks: Ground Water, v. 48, no. 3, p. 401-415, accessed April 22, 2018, at https://doi.org/10.1111/j.17456584.2009.00651.x.

Tiedeman, C.R., Shapiro, A.M., Hsieh, P.A., Imbrigiotta, T.E., Goode, D.J., Lacombe, P.J., DeFlaun, M.F., Drew, S.R., Johnson, C.D., Williams, J.H., and Curtis, G.P., 2018, Bioremediation in fractured Rock: 1. Modeling to inform design, monitoring, and expectations: Groundwater, v. 56, no. 2, p. 300-316, accessed April 22, 2018, athttps://doi.org/ 10.1111 /gwat.12585.

U.S. Geological Survey, 2019, USGS water data for the Nation: U.S. Geological Survey National Water Information System database, accessed April 26, 2019, at https://doi.org/10.5066/F7P55KJN. 
For additional information, contact:

Director, New Jersey Water Science Center U.S. Geological Survey

3450 Princeton Pike, Suite 110

Lawrenceville, NJ 08648

Or visit our website at: https://www.usgs.gov/centers/nj-water

Publishing support provided by the West Trenton Publishing Service Center 


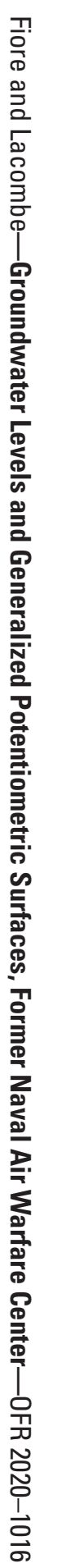

